\title{
Development of outdoor thermal comfort model for tourists in urban historical areas;
}

\author{
A case study in Isfahan
}

\author{
Nazanin Nasrollahi ${ }^{1^{*}}$, Zhila Hatami ${ }^{1}$, Mohammad Taleghani ${ }^{2}$ \\ ${ }^{1}$ Department of Architecture, Faculty of Technology and Engineering, Ilam University, \\ Pazhohesh Boulevard, Ilam, Iran \\ ${ }^{2}$ School of the Built Environment, University of Salford, Manchester, UK
}

\begin{abstract}
Outdoor thermal comfort is one of the most important issues for tourists' visits of historical sites in urban context. The present study intended to evaluate thermal comfort conditions in the microclimates of the urban historical textures of Isfahan, Iran, during a heatwave. The thermal comfort conditions of different urban textures were compared during the daylight hours to determine the best time of the day to visit each historical site. Using the results of this study, tourists can select the best timeframe with appropriate thermal conditions to visit the historical sites of Isfahan. Various measurements, questionnaire and simulation tools were used in this study. Along with performing field measurements in the intended historical sites, a questionnaire was used to determine the thermal comfort range of tourists. After data validation in ENVI-met software, the microclimates of the urban historical textures of Isfahan were simulated and compared in order to determine the average warmest month of the year in Isfahan. The thermal comfort sensation of tourists at the historical textures of Isfahan ranges from 23.06 to $29.73{ }^{\circ} \mathrm{C}$ $\mathrm{PET}^{1}$. During the daytime, thermal comfort conditions varied from $4.9^{\circ} \mathrm{C}$ PET at 8 am to $8.1{ }^{\circ} \mathrm{C}$ PET at $3 \mathrm{pm}$. Early morning hours were the most comfortable time to visit the historical textures of Menar-e-Jonban ${ }^{2}$, Masjed-e-Jame ${ }^{3}$ and Vank Cathedral in Isfahan. The central courtyard of Masjed-e-Jame had the best thermal comfort conditions during the daylight hours. During the peak hours of heat, the priority of thermal comfort goes to Masjed-e-Jame, Menar-e-Jonban and Si-o-
\end{abstract}

\footnotetext{
1 Physiological Equivalent Temperature

2 Shaking Minaret in Isfahan

3 Grand Mosque of Isfahan
} 
$\mathrm{Se} \mathrm{Pol}^{4}$, respectively. The thermal comfort conditions of Naqsh-e-Jahan Square ${ }^{5}$, Si-o-Se Pol and Hasht Behesht Palace ${ }^{6}$ have approximated to the favorable comfort range during the nighttime. Therefore, it is recommended to visit these historical sites during the nighttime in terms of thermal comfort.

Key words: Outdoor thermal comfort, Field survey, Comfort ranges, Tourist, ENVI-met, Urban Historic Context, Climate Comfort Pattern

\section{Introduction}

\subsection{Climate and Tourism}

As one of the most diverse and largest industries in the world, tourism industry is the paramount source of income and employment opportunities for many countries in the world. Due to its economic and social significance, tourism industry has increasingly become the center of attention for many governments. Nowadays, it is also one of the key tenets of the world's economy and one of the fastest growing industries in the global economic development. Creating appropriate conditions for the development of tourism industry is essential. Amongst the main natural factors affecting tourism, climate has a crucial role [1,2]. Climate is a critical factor in determining the touristic areas [3,4] and affects tourism demand in different seasons [5]. Tourists are more sensitive to climate conditions than local people [6]; they are usually looking for a climate where they don't have a feeling of thermal discomfort and dissatisfaction [7]. Providing information about the right time of visit help tourists schedule their time [8]. The information about the climate conditions of touring days is greatly important for tourism planners [9]. Integrated evaluation of the physical beauty and thermal comfort conditions of touring sites improves the capabilities of touristic areas [10]. Analysis of climate data [11] and climate information maps are useful for tourists to make the best decisions [12,13]. For instance, very few tourists visit the Sun Moon Lake in Taiwan. As most of the visitors are from China, it is recommended to provide appropriate climate information about the thermal comfort sensation of Chinese people for other visitors to make a visit [14].

\subsection{Literature Review on Tourism}

\footnotetext{
${ }^{4}$ A Thirty-Three Stone Double-deck Arch Bridge in Isfahan

5 A Square Situated at the Center of Isfahan

6 Literally means 'Eight Heavens", it is a historical Palace in Isfahan
} 
In 1985, Mieczkowski developed a tourism climate comfort index (TCCI) with 7 climatic factors to determine and evaluate climatic suitability for tourists [15]. Freitas outlined various aspects of tourism climate; he believes that tourism climate can be evaluated based on three fundamental aesthetic, physical and thermal aspects [13]. Matzarakis and Mayer evaluated the heat stress of 12 meteorological stations in Germany based on $\mathrm{PMV}^{7}$ index during 1980-1989 and converted the PMV value of each station to a climatology map [7]. Yan evaluated human comfort zone in different parts of China during 1960-1998 [16]. Lin and Matzarakis studied the thermal comfort of the Sun Moon Lake in Taiwan [14]. In a study on the north west of Iran, the thermal comfort index (PET) and tourist climate index (TCI) were evaluated using the data provided by 15 meteorological stations during the intended years [10]. Lin and Matzarakis evaluated several climatic parameters in the tropical and temperate regions of Taiwan and Eastern China, investigated its relationship with thermal comfort of tourists and ultimately determined the suitable time for tourism in these regions [8]. Çalışkan, et al. in 2012studied the climatic conditions of Bursa, Turkey from the perspective of tourists; they used PET's comfort index and CTIS ${ }^{8}$ [17]. In a study, the Hunter region of Australia evaluated using CTIS [18]. Several studies have been done on tourism in different areas such as Luxemburg in the central Europe [19] and southwestern China [20]. Research has evaluated the impact of climate change [21] on tourists [22]. Hamilton and Tol studied Germany, England and Ireland [23], Scott et al. evaluated Rocky Mountains of Canada [24] and Amelung and Moreno studied Europe in this regard [25].

Review of the studies on different climates reveled that most of these research were conducted on a large scale (city, country or continent) using data provided by different meteorological stations to estimate the relevant indices and ultimately determine the suitable thermal comfort range for tourists in terms of appropriate days or months of the year.

\subsection{Thermal Comfort of Urban Texture}

Urban texture has a significant impact on microclimates [26] and various thermal conditions in its surrounding environment. Several studies have evaluated thermal comfort conditions in urban microclimates [27-28]. There is a strong relationship between microclimates and the use of outdoor spaces and environments [29]. Comfortable climates attract more people to touristic sites [30].

\footnotetext{
7 Predicted Mean Vote Index

8 Climate Tourism Information Scheme
} 
Thermal comfort is of utmost importance due to its impact on human health [31], urban vitality [32] and energy consumption of buildings [33]. It is necessary to recognize the factors affecting thermal comfort in order to create convenient conditions [34,35]. Plans and geometry of urban spaces are the effective factors in creating microclimates across the city [36]. Direction [37], sky view factor (SVF) $[38,39]$ and aspect ratio (known as built up ratio) $[40,41]$ are also important geometrical factors affecting urban microclimates. Furthermore, urban greenery has been studied in many research $[42,43]$.

Climate changes and fluctuations play crucial role in the quality of comfort, and consequently on tourists throughout the day. Different urban climates have different thermal conditions during the daytime. Despite the unfavorable thermal conditions in the dry and hot summers of Isfahan, Iran, visiting the historical monuments in this season has got high statistics. Therefore, paying attention to the thermal comfort of tourists is important. Thermal comfort conditions of microclimates, created across the city (including historical sites) are different even during the same time of a day. The present study compares the thermal comfort conditions of different microclimates of urban texture based on which tourists can select the most suitable time for visiting each urban historical texture at different time of the day with high heat stress.

\section{Materials and Methods}

\subsection{Research Site}

According to Koppen-Geiger's climate classification, Isfahan $\left(51^{\circ} 39^{\prime} \mathrm{N}, 32^{\circ} 38^{\prime}\right.$ E) has a dry climate [44]. Dry weather and low precipitation (little rainfall) are the main characteristics of this type of climate in which the maximum temperature is $40.6^{\circ} \mathrm{C}$, minimum temperature is $-10.6^{\circ} \mathrm{C}$ and average annual temperature is $16.7^{\circ} \mathrm{C}$, as recorded. The number of frost days is 76 days, and the average annual precipitation is $116.9 \mathrm{~mm}$ [45].

Six historical textures of Isfahan, such as Naqsh-e-Jahan Square, Masjed-e-Jame, Si-o-Se Pol, Menar-e-Jonban, Hasht Behesht Palace and Vank Cathedral, were selected to evaluate their thermal comfort conditions The location of these historical sites are displayed in Figure 1. These urban textures are registered in the Cultural Heritage Organization of Iran. Based on the purpose of this study, the other parameter to select the aforesaid urban historical textures was the presence of distance between the selected textures because the probability of visiting various historical 
monuments and sites with short distances at a given time rises. Figure 2 shows some images of the intended touristic sites.

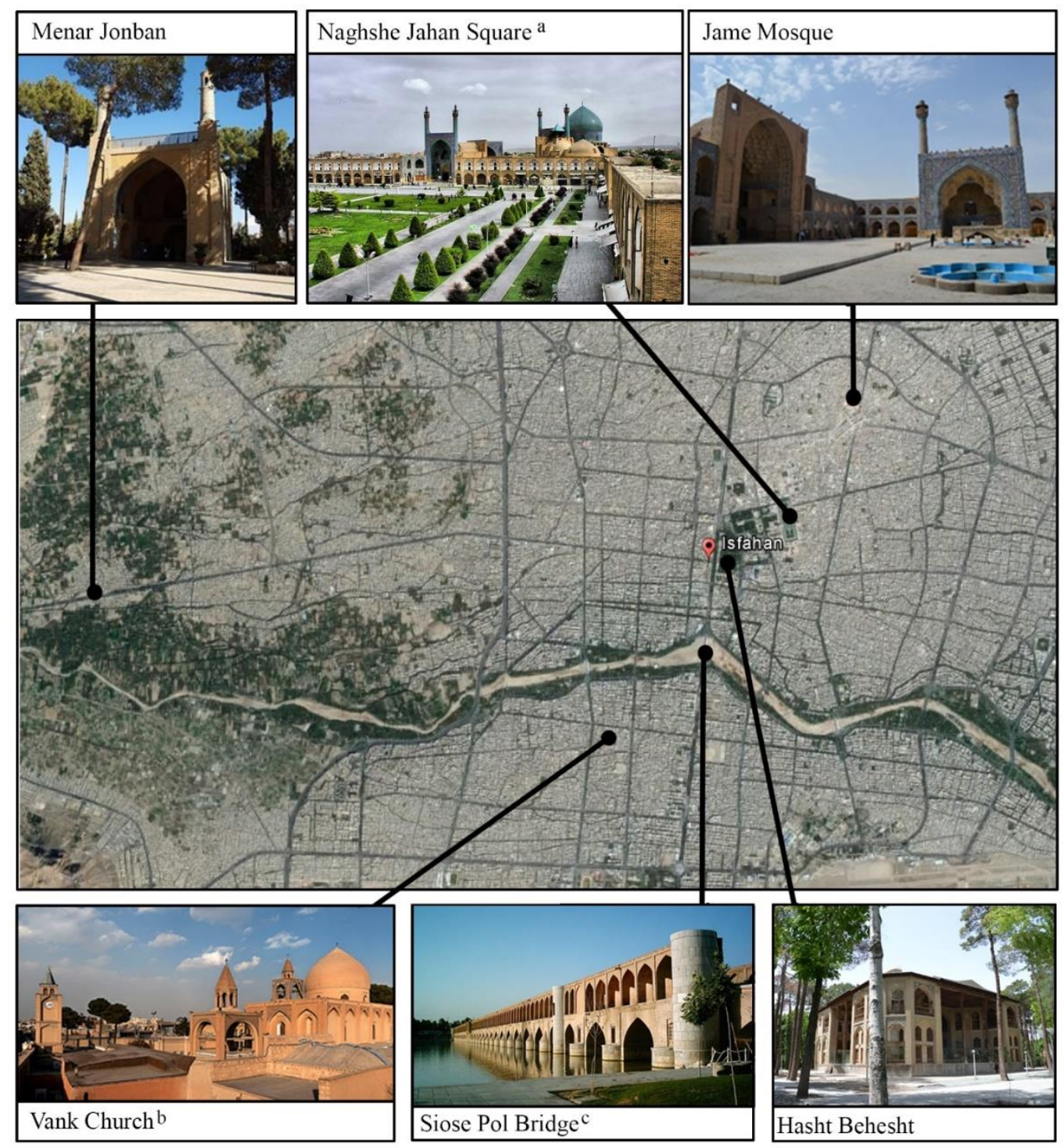

Figure 1 Locations of historical places in Isfahan (source a: http://arfatour.com, source/, b: https://fa.wikipedia.org/, source c: http://www.tishineh.com/. 

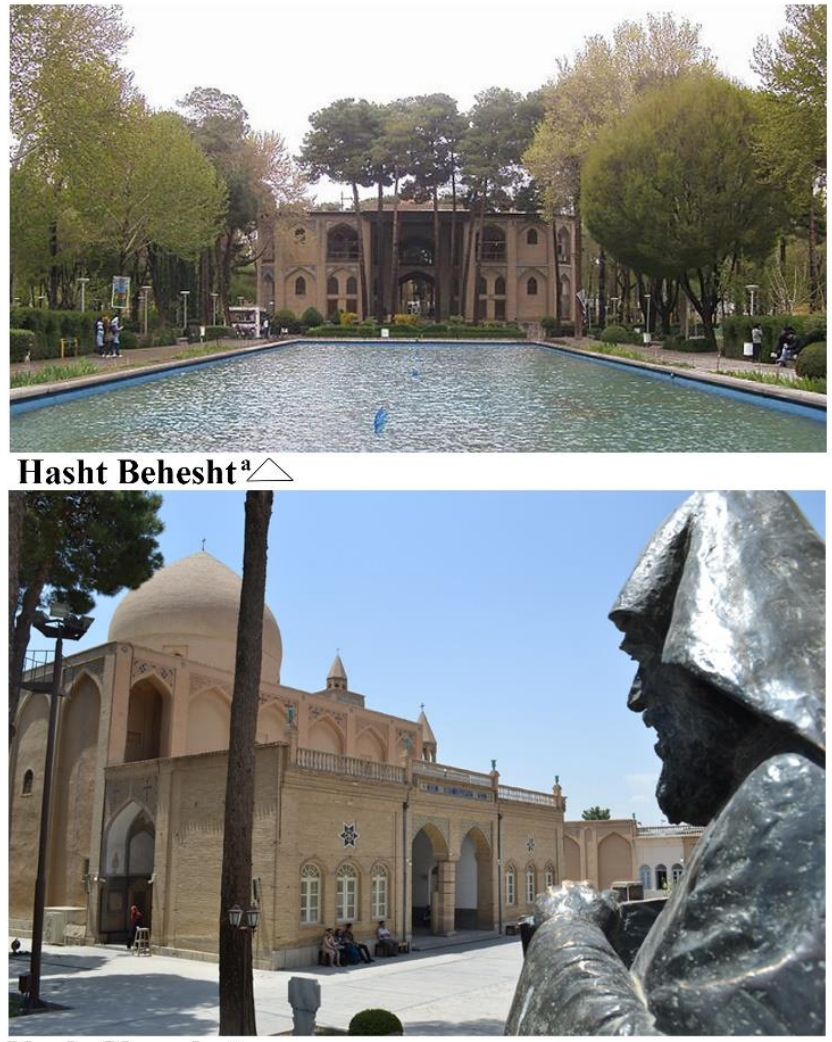

Vank Church $\triangle$

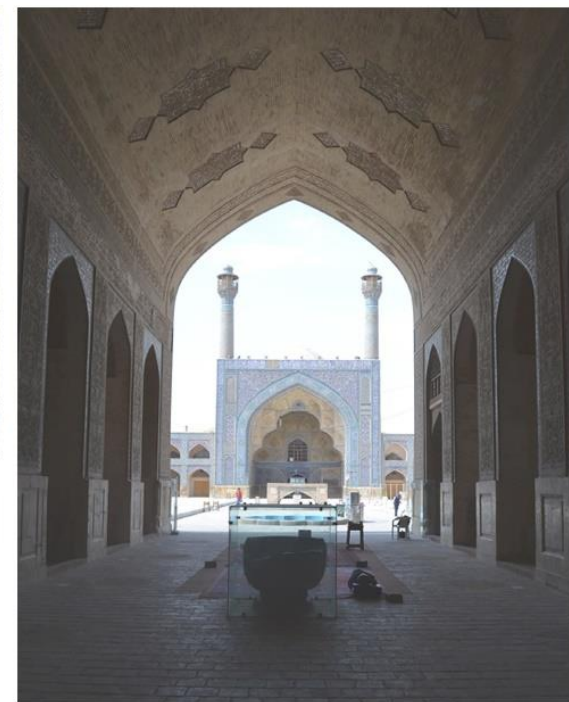

Jame Mosque $\triangle$

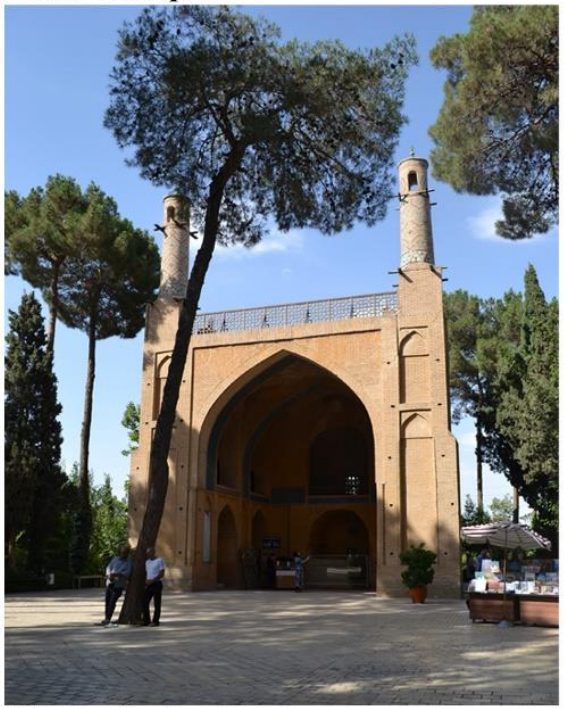

Menar Jonban $\triangle$

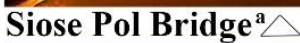

Naghshe Jahan Square $^{a} \nabla$

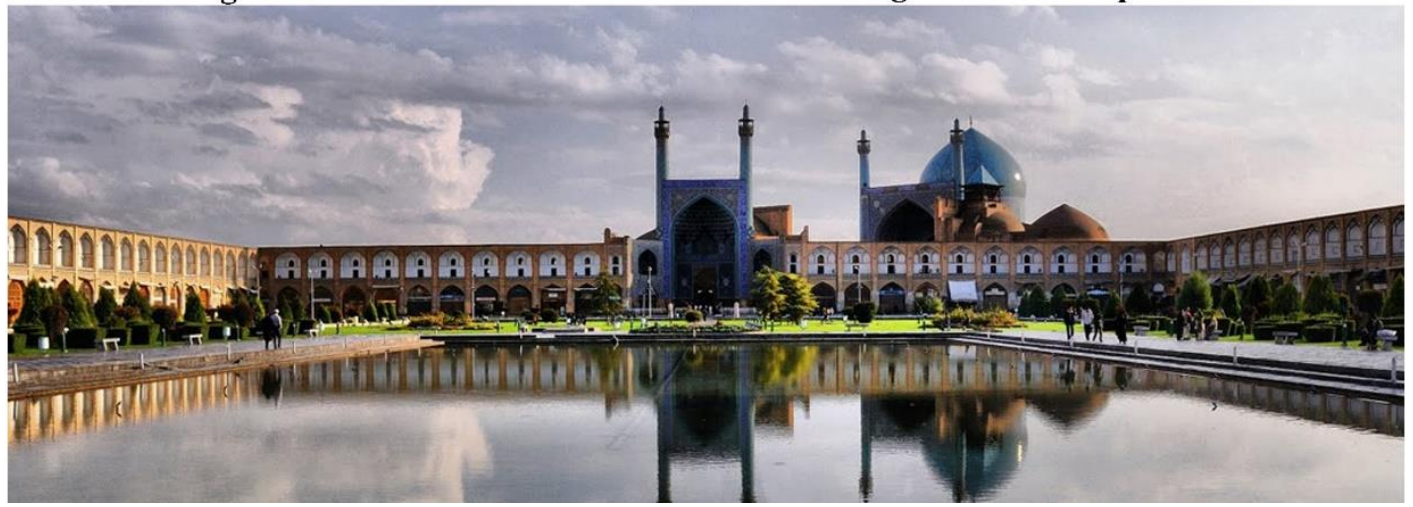

Figure 2 Pictures of the study sites (source a: http://arfatour.com/). 


\subsection{Research period}

The present study aimed at finding the most appropriate time for tourists visiting each historical site. The research was conducted for the warmest month of the year (July $12^{\text {th }}-21^{\text {st }}$ ), so that the tourists would be able to select the best time of the day for visiting each site despite the unfavorable thermal conditions. Field measurements were done in each historical texture to ensure the validation of CFD simulations by ENVI-met. Moreover, questionnaires were distributed and completed at 10 am-12 pm, 5-8 pm for the sites with limited visiting hours, and 5-8 pm for other sites. Table 1 presents the days and hours of field studies in details.

Table1. Description of the date of field surveys at each area.

\begin{tabular}{ccccccc}
\hline & $\begin{array}{c}\text { Naghshe } \\
\text { Jahan } \\
\text { square }\end{array}$ & $\begin{array}{c}\text { Hasht } \\
\text { Behesht }\end{array}$ & $\begin{array}{c}\text { Menar } \\
\text { Jonban }\end{array}$ & $\begin{array}{c}\text { Vank } \\
\text { Church }\end{array}$ & $\begin{array}{c}\text { Jame } \\
\text { Mosque }\end{array}$ & $\begin{array}{c}\text { Siose Pol } \\
\text { Bridge }\end{array}$ \\
\hline $\begin{array}{c}\text { Date of } \\
\text { measurement }\end{array}$ & $7 / 13 / 2016$ & $7 / 14 / 2016$ & $7 / 17 / 2016$ & $7 / 19 / 2016$ & $7 / 20 / 2016$ & $7 / 21 / 2016$ \\
\hline $\begin{array}{c}\text { Date of } \\
\text { questionnaire } \\
\text { survey }\end{array}$ & $7 / 12 / 2016$ & $7 / 13 / 2016$ & $7 / 17 / 2016$ & $7 / 19 / 2016$ & $7 / 16 / 2016$ & $7 / 14 / 2016$ \\
\hline $\begin{array}{c}\text { Time of } \\
\text { questionnaire } \\
\text { survey for each } \\
\text { survey day }\end{array}$ & $17 \mathrm{amm}-12 \mathrm{am}$ & $10 \mathrm{am}-12 \mathrm{am}$ & $10 \mathrm{am}-12 \mathrm{am}$ & $10 \mathrm{am}-12 \mathrm{am}$ & $10 \mathrm{am}-12 \mathrm{am}$ & $10 \mathrm{am}-12 \mathrm{am}$ \\
\hline $\begin{array}{c}\text { Number of } \\
\text { valid }\end{array}$ & $49 \mathrm{pm}-20 \mathrm{pm}$ & $17 \mathrm{pm}-19 \mathrm{pm}$ & $17 \mathrm{pm}-19 \mathrm{pm}$ & $17 \mathrm{pm}-19 \mathrm{pm}$ & $17 \mathrm{pm}-20 \mathrm{pm}$ \\
questionnaire & 49 & 46 & 45 & 48 & 48 \\
\hline
\end{tabular}

\subsection{Field Study}

\subsubsection{Measurement}

In order to validate the simulation done by ENVI-met, and to determine the thermal comfort zones, measurements were performed at the height of 1 meter from the ground surface in each historical texture. The relative humidity and air temperature of each historical sites were measured by Standard ST-174B sensor, while the relative humidity, air temperature and wind speed were measured at the time of questionnaire completion by Fluke 975 sensor (Figure 3). All devices and sensors complied with the standards of ISO 7726 [46]. Table 2 presents the technical details of climate measurement sensors. 
Table2. Description of the date of field survey of each area.

\begin{tabular}{|c|c|c|c|c|c|}
\hline Variable & Symbol & Unit & Instrument & Accuracy & Range \\
\hline Air temperature & $\mathrm{Ta}$ & ${ }^{\circ} \mathrm{C}$ & $\begin{array}{c}\text { Standard ST-174B Weather } \\
\text { Datalogger }\end{array}$ & $\mathrm{C}^{\circ} \pm 1$ & $C^{0^{\circ}}-40$ to 70 \\
\hline Relative humidity & RH & $\%$ & $\begin{array}{c}\text { Standard ST-174B Weather } \\
\text { Datalogger }\end{array}$ & $\pm 3 \%$ & 0\% to $90 \%$ RH \\
\hline Wind velocity & WS & $\mathrm{m} / \mathrm{s}$ & Fluke 975 air meter & $\pm 0.02 \mathrm{~m} / \mathrm{s}$ & 0.25 to $15 \mathrm{~m} / \mathrm{sec}$ \\
\hline Air temperature & $\mathrm{Ta}$ & ${ }^{\circ} \mathrm{C}$ & Fluke 975 air meter & $\pm 0.5^{\circ} \mathrm{C}$ & $-20^{\circ} \mathrm{C}$ to $50^{\circ} \mathrm{C}$ \\
\hline Relative humidity & RH & $\%$ & Fluke 975 air meter & $\pm 2 \%$ & $10 \%$ to $90 \% \mathrm{RH}$ \\
\hline
\end{tabular}

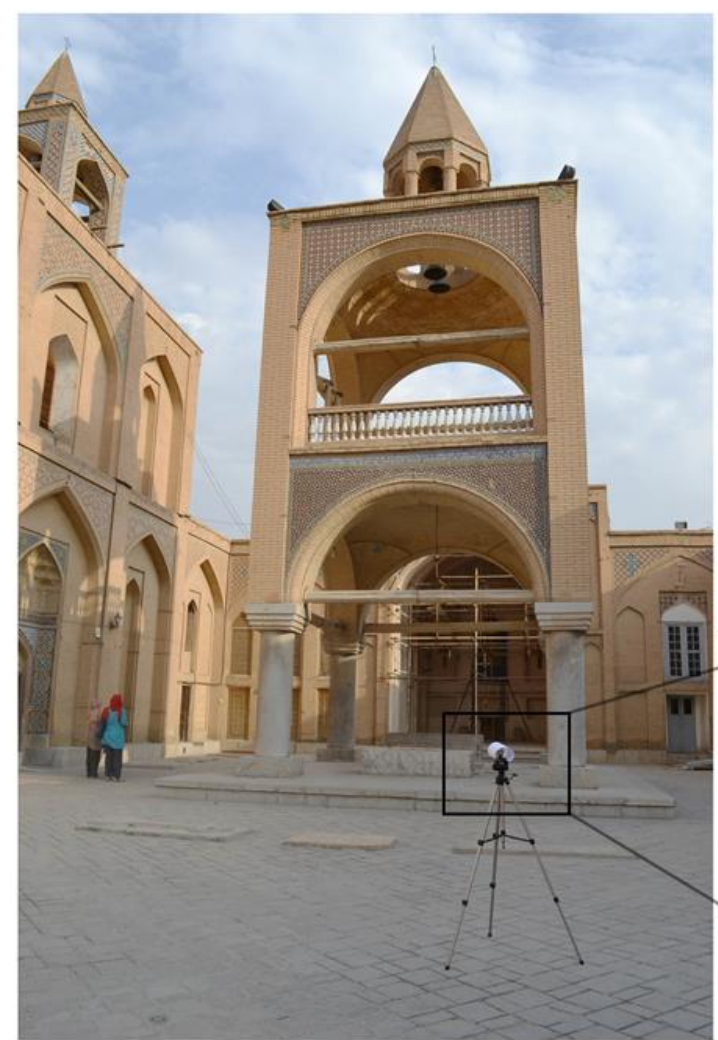

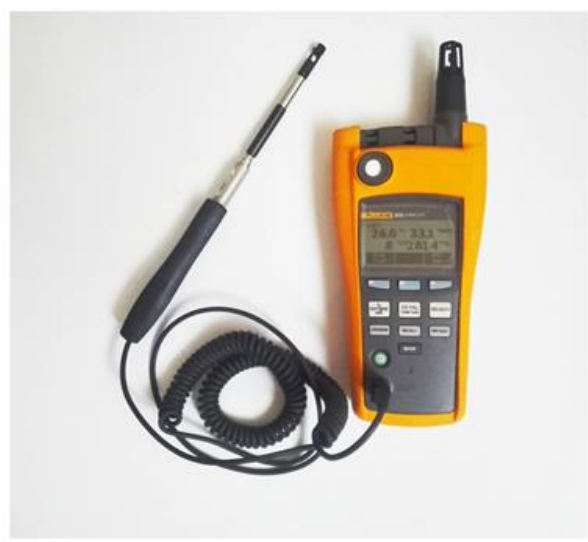

Fluke 975 Airmeter for measuring air temperature, relative humidity and wind velocity when tourist answer the questionnaire

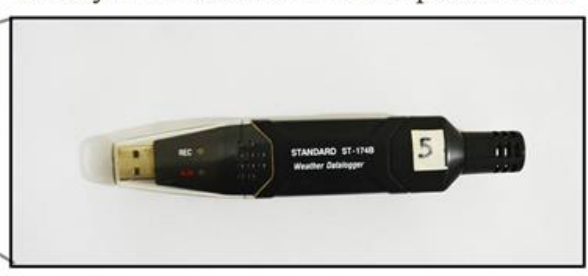

Standard ST-174B Weather Datalogger for measuring air temperature and relative humidity to validate Envi-met software

Figure 3. Data loggers for measurement of microclimate parameters.

\subsubsection{Questionnaire}

Climate conditions affect people's thermal comfort sensation. Along with completing the questionnaires, the climate variable such as air temperature, humidity and wind speed were measured at a distance of 1 meter from the tourists. The questionnaire consisted of two sections. The first section was related to tourists' personal information including gender, weight, height, 
city and place of residence etc. The second section was about the tourists' thermal sensation, thermal preference, thermal satisfaction, length of stay in the city, type of activity, their presence in the intended historical site before completing the questionnaire, length of visiting the intended historical monument as well as other questions affecting their thermal sensation. Although the present study discussed tourists' thermal sensation and satisfaction in general, the questionnaire was developed in consistence with previous studies [47-49] and ASHRAE-55 Standard [50]. The questionnaire was prepared in Persian and English versions for both domestic and foreign tourists. Figure 4 displays a sample of the main items of the questionnaire. Simple random sampling method was used to select domestic and foreign tourists from different parts of the intended historical textures. It took 5 minutes to complete each questionnaire.

Tourists were interviewed about their thermal comfort sensation. In accordance with most studies, the questionnaire had a 7-point scale i.e. very cold (-3), cold (-2), slightly cold (-1), comfortable (0) slightly warm (+1), warm (+2) and very warm (+3) to assess tourists' thermal comfort sensation [51]. This scale was in compliance with ASHRAE Standard 55 [50] which has been used in recent studies [52-54]. Figure 5 shows a tourist completing the questionnaire at Vank Cathedral.

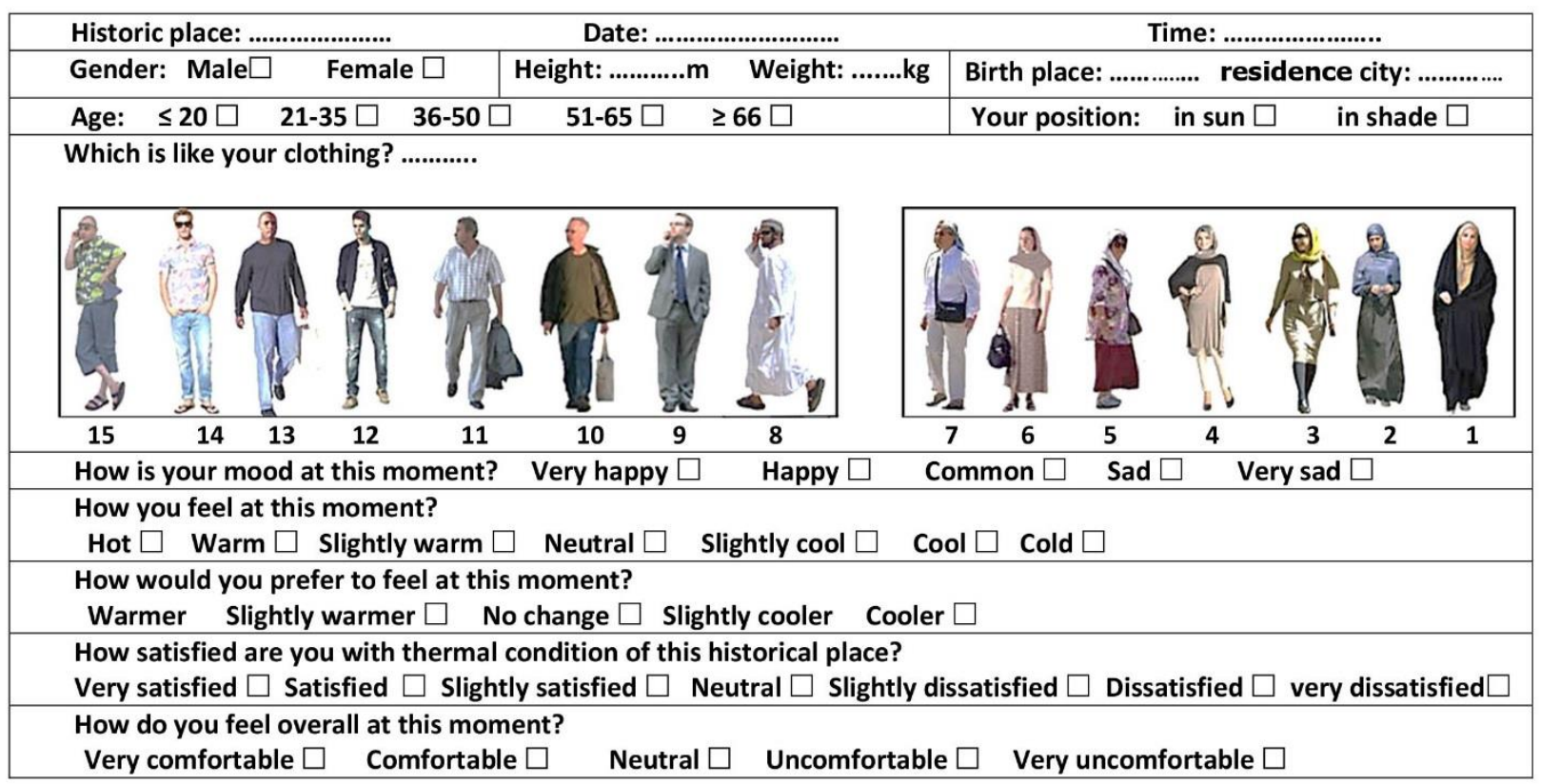




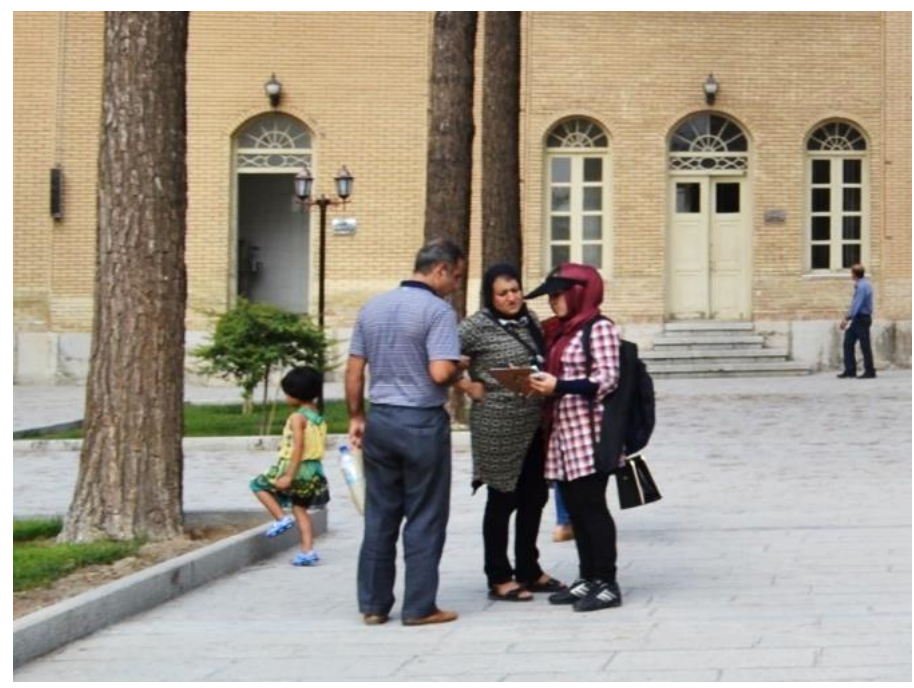

Figure 5. Tourists while answering the questionnaire in Vank church.

\subsection{Validation}

The accuracy of ENVI-met results are assessed in many studies by comparing the results of simulation and field measurement. These studies have shown that ENVI-met is able to simulate outdoor thermal environment of different climate models and has an acceptable accuracy [55-58].

To maximize the accuracy of the simulations done for the present study, the simulation models of six case studies were validated. According to the comparison diagrams of simulated versus measured temperature (Figure. 6), the maximum temperature difference was in the peak hours of heat (i.e. $4^{\circ} \mathrm{C}$ ). The temperature difference ranging from 2 to $4^{\circ} \mathrm{C}$ was acceptable due to vertical divergent wavelengths were not considered in ENVI-met software [59]. Hence, ENVI-met was an acceptable tool to simulate microclimates in Isfahan. In order to maximize the accuracy of the present study, the coefficients of variations were used in comparing the comfort conditions of each environment. By averaging the measured divided by simulated air temperatures, the coefficient of error in each historical site was used in the ultimate comparison of the comfort conditions of historical sites (Table 3). 

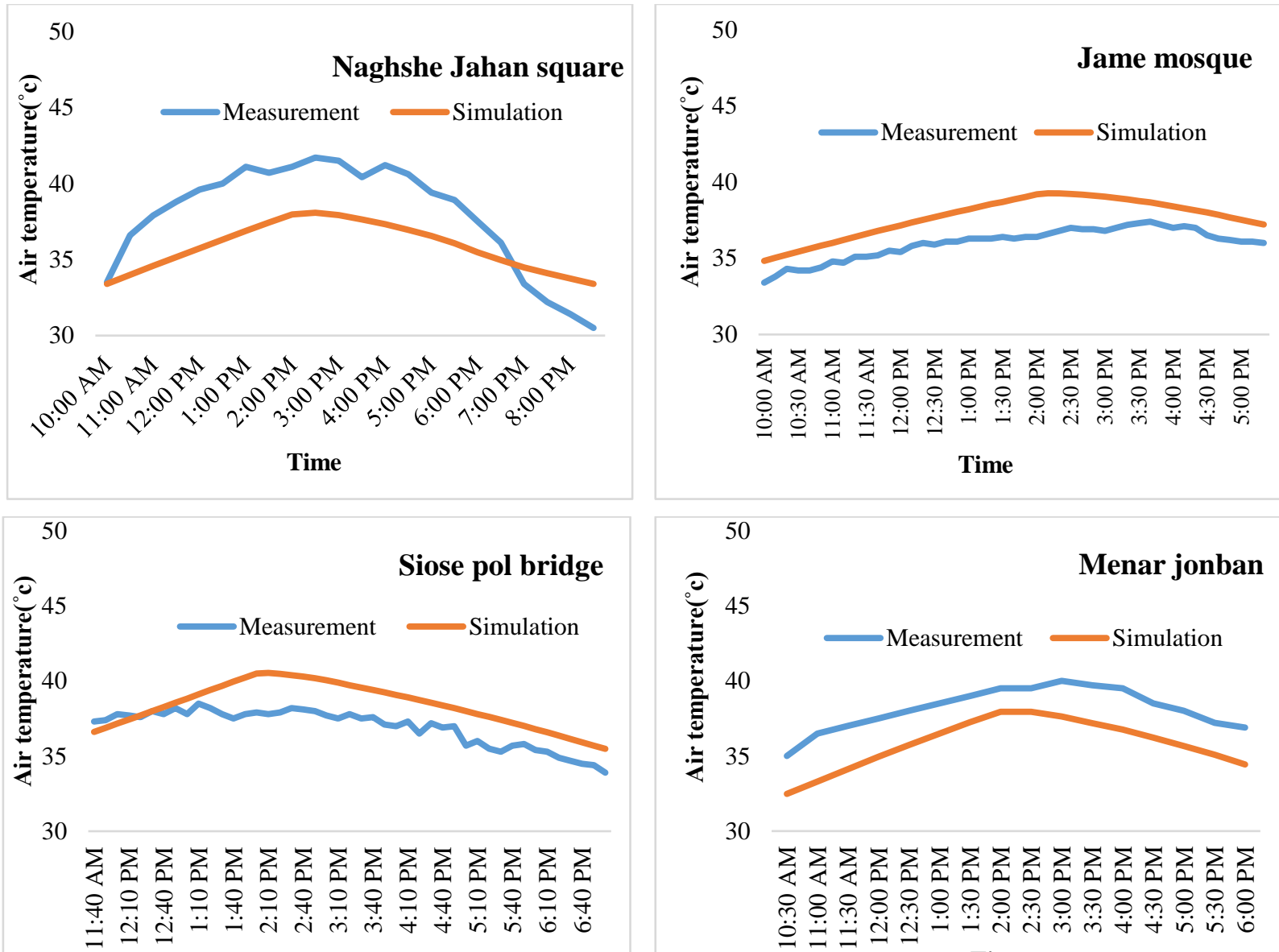

Time
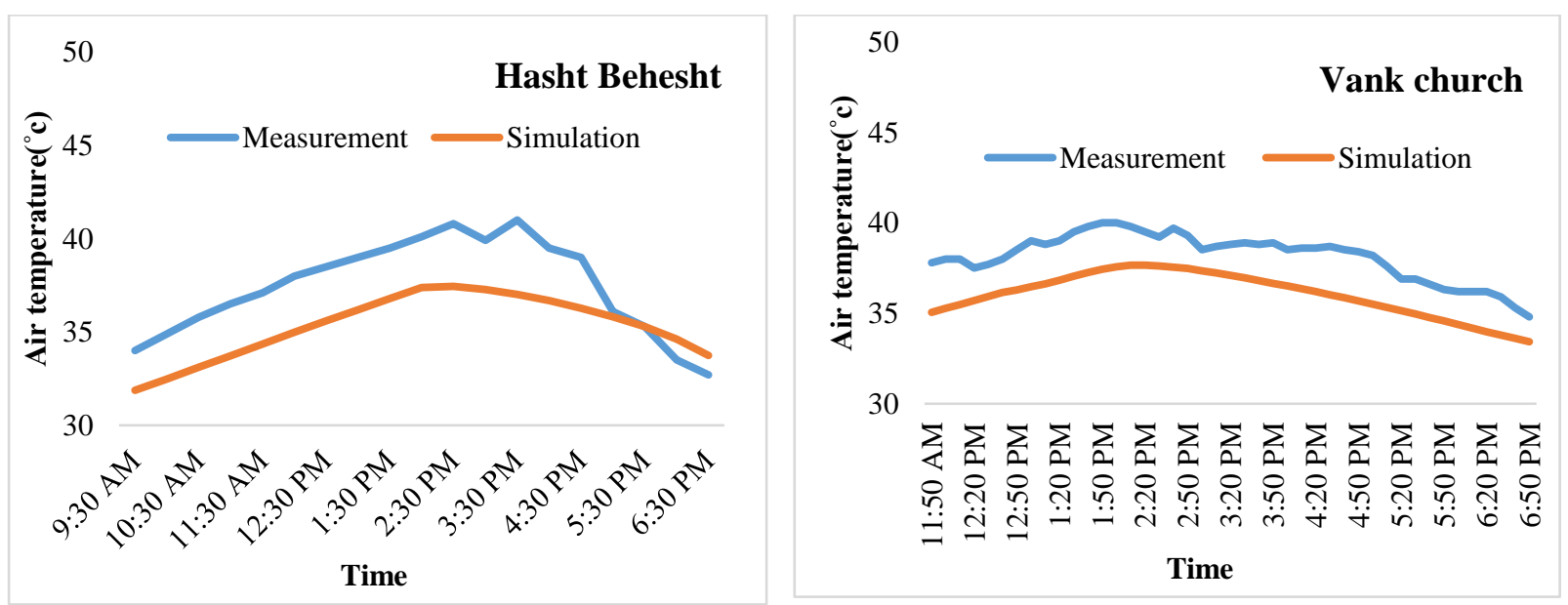

Figure 6. A comparison of air temperature between measurement and simulation in each historical place.

Table 3. Error rates of simulations for each historical place.

\begin{tabular}{lllllll}
\hline Historical place & $\begin{array}{l}\text { Naghshe } \\
\text { jahan square }\end{array}$ & Jame mosque & $\begin{array}{l}\text { Vank } \\
\text { church }\end{array}$ & $\begin{array}{l}\text { Menar } \\
\text { Jonban }\end{array}$ & Hasht Behesht & $\begin{array}{l}\text { Siose pol } \\
\text { bridge }\end{array}$ \\
\hline $\begin{array}{l}\text { Error rate of } \\
\text { simulation }\end{array}$ & $1 / 05$ & $0 / 93$ & $1 / 05$ & $1 / 06$ & $1 / 05$ & $\mathbf{0 / 9 7}$ \\
\hline
\end{tabular}




\subsection{Simulation}

The average warmest month of the year was considered for simulating the historical textures in ENVI-met. The simulated outputs including air temperature, relative humidity, wind speed and mean radiant temperature were used as inputs in RayMan software to calculate the PET's thermal comfort index.

Six historical sites along with their urban textures were simulated (Figure. 7). Three historical sites of Masjed-e-Jame, Vank Cathedral and Menar-e-Jonban were open to visit from 8 am to $7 \mathrm{pm}$ while the other three historical sites of Naqsh-e-Jahan Square, Si-o-Se Pol and Hasht Behest Palace were open to visit without any time limitation. Therefore, the comfort conditions of these historical sites were simulated until 12 at midnight. Simulations began about 5 hours prior to 8 am to increase the accuracy of simulation results. The details of simulations are presented in Table 4 .

The ten-year average data of Isfahan's meteorological stations were used as inputs in ENVI-met. Air temperature, relative humidity, wind speed and other inputs of ENVI-met configurations are shown in Table 5.

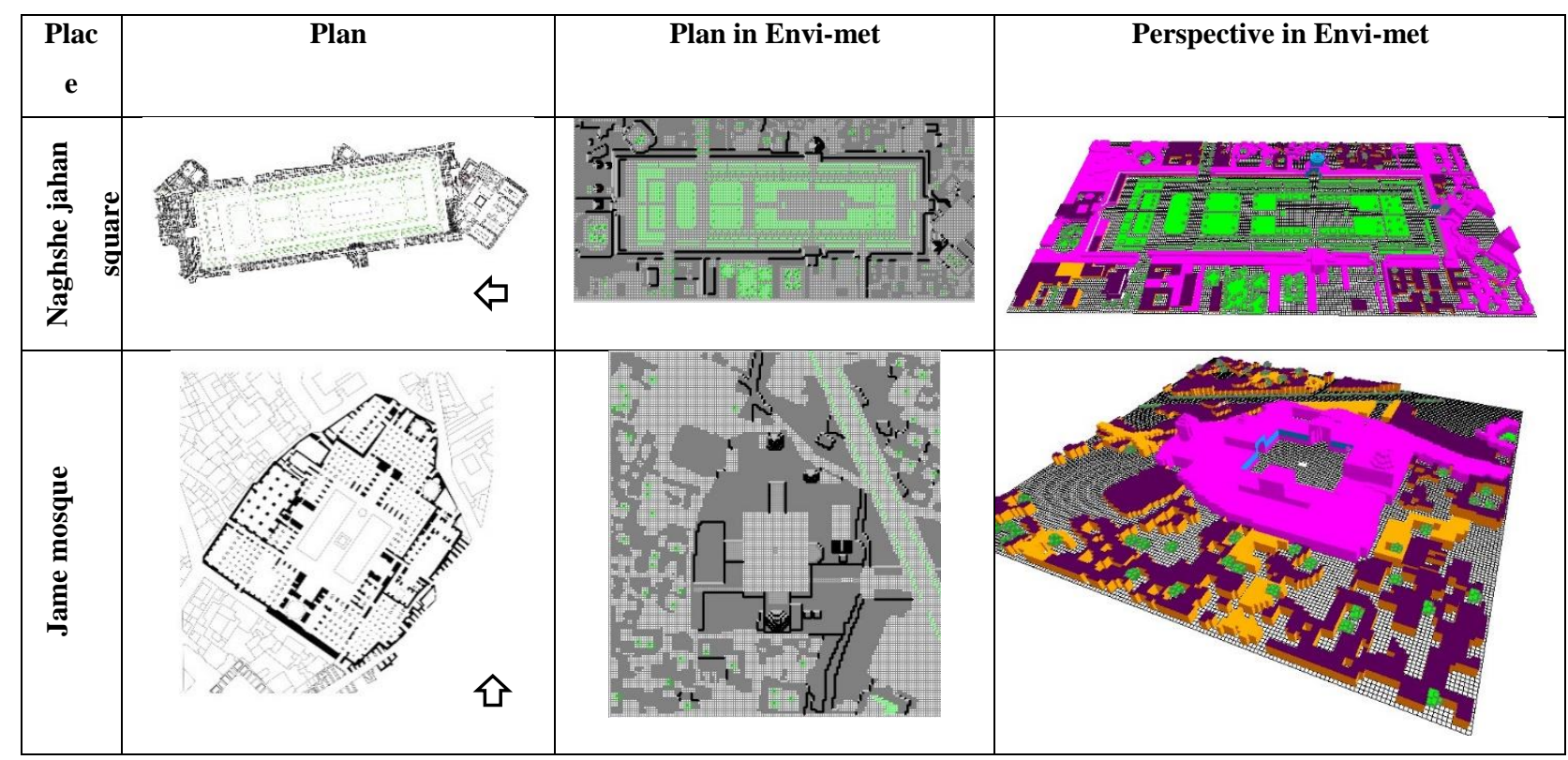




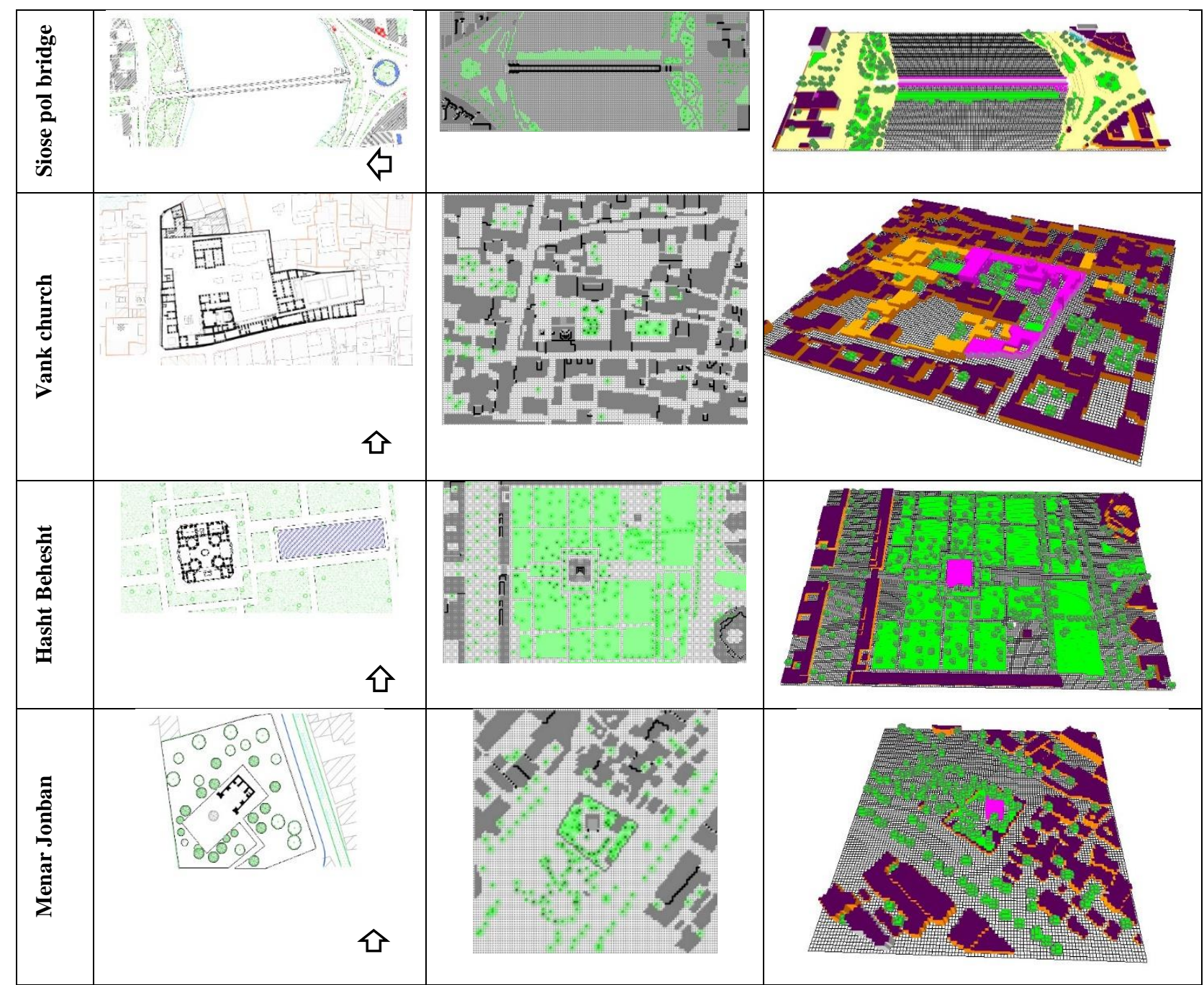

Figure 7. Plan and perspective of the study site in each simulation model.

Table 4. Description of the model simulation of each area.

\begin{tabular}{|c|c|c|c|c|c|c|}
\hline \multirow[t]{2}{*}{ Model parameters } & \multicolumn{6}{|l|}{ Area } \\
\hline & $\begin{array}{c}\text { Naghshe } \\
\text { Jahan square }\end{array}$ & $\begin{array}{l}\text { Siose Pol } \\
\text { Bridge }\end{array}$ & $\begin{array}{c}\text { Hasht } \\
\text { Behesht }\end{array}$ & $\begin{array}{l}\text { Menar } \\
\text { Jonban }\end{array}$ & $\begin{array}{c}\text { Vank } \\
\text { Church }\end{array}$ & $\begin{array}{c}\text { Jame } \\
\text { Mosque }\end{array}$ \\
\hline Number of grid cells $(x, y, z)$ & $113,240,29$ & $97,239,24$ & $211,131,24$ & $\begin{array}{l}104,103, \\
30\end{array}$ & $147,11,30$ & $144,156,30$ \\
\hline Size of grid cells(meter) $(x, y, z)$ & $\begin{array}{c}3,3, \\
\text { Increasing } \\
\text { with height }\end{array}$ & $2.5,2.5,1$ & $2,2,1$ & $2,2,1$ & $2,2,1$ & $\begin{array}{c}2,2, \\
\text { Increasing } \\
\text { with height }\end{array}$ \\
\hline $\begin{array}{l}\text { Model rotation out of grid } \\
\text { north }\end{array}$ & -12 & 6 & 6 & 45 & -11 & 35 \\
\hline Start-end time & 03:00-24:00 & $\begin{array}{l}03: 00- \\
24: 00\end{array}$ & 03:00-24:00 & $\begin{array}{l}\text { 03:00- } \\
19: 00\end{array}$ & $\begin{array}{l}03: 00- \\
19: 00\end{array}$ & 03:00-19:00 \\
\hline Total duration & $21 \mathrm{~h}$ & $21 \mathrm{~h}$ & $21 \mathrm{~h}$ & $16 \mathrm{~h}$ & $16 \mathrm{~h}$ & $16 \mathrm{~h}$ \\
\hline
\end{tabular}


Table 5. Description of the model meteorological boundary configurations.

\begin{tabular}{|c|c|c|c|c|c|c|c|c|}
\hline \multicolumn{9}{|c|}{ Parameter } \\
\hline \multicolumn{2}{|c|}{$\begin{array}{c}\text { Air temperature } \\
\left({ }^{\circ} \mathrm{C}\right)\end{array}$} & \multicolumn{2}{|c|}{$\begin{array}{c}\text { Specific } \\
\text { humidity }(\%)\end{array}$} & \multirow[t]{2}{*}{$\begin{array}{c}\text { Wind speed in } 10 \\
\text { m height }(\mathrm{m} / \mathrm{s})\end{array}$} & \multirow{2}{*}{$\begin{array}{c}\text { Wind } \\
\text { direction } \\
\left(^{\circ}\right)\end{array}$} & \multirow[t]{2}{*}{$\begin{array}{l}\text { Cloud cover } \\
\text { (octans) }\end{array}$} & \multirow[t]{2}{*}{$\begin{array}{l}\text { Roughness } \\
\text { length }\end{array}$} & \multirow{2}{*}{$\begin{array}{l}\text { Solar } \\
\text { adjust } \\
\text { Factor }\end{array}$} \\
\hline Max & Min & Max & Min & & & & & \\
\hline 40.82 & 18.74 & 29.79 & 9.70 & $1.97 \mathrm{~m} / \mathrm{s}$ & 45 & 0 & .01 & 1 \\
\hline
\end{tabular}

\subsection{Thermal Comfort Index}

There are many indices to evaluate outdoor thermal comfort. For instance, the indices of $\mathrm{PMV}^{9}$ [61], SET ${ }^{10}$ [62], ET [63], OUT-SET ${ }^{11}$ [10], UTCI [64-65], PET [66] and ETFE [67] are used for outdoor environment. PET's thermal comfort index is based on thermos-physiological energy balance in the human body (Munich Energy Balance Model for Individuals (MEMI)) [66]. PET is known as the air temperature that makes the human body's thermal conditions in indoor environment in balance with the body's skin and core temperature in complicated outdoor environment. Therefore, one can compare the outdoor temperature with his/her experience of indoor temperature conditions. PET is calculated by RayMan [68-69]. The required parameters for calculating PET's thermal comfort index in RayMan include air temperature, relative humidity, wind speed, mean radiant temperature, human's clothing, and activity.

PET index has been approved by Germany's VDI standard and is used as the outdoor thermal comfort index [70]. It has also been used in many studies to assess outdoor environments with different climates [53-71]. Therefore, it is possible to compare the results of the present study with the accepted comfort ranges in different areas which can be used by foreign tourists with different climates.

\section{Results}

\subsection{Questionnaire results}

The questionnaire was distributed in different parts of the historical sites to evaluate thermal comfort sensation. A total number of 291 questionnaires was completed within 6 days in the morning and evening, 20 of which were excluded from the analysis due to the presence of less

\footnotetext{
9 Predicted Mean Vote

10 Standard Effective Temperature

11 Outdoor Standard Effective Temperature
} 
than 15 minutes in the intended sites. The maximum number of completed questionnaires was 49 in Naqsh-e-Jahan Square and the minimum number was 45 in Menar-e-Jonban and Si-o-Se Pol.

In general, the participants consisted of $\% 55.36$ male and $\% 44.64$ female. The questionnaires were completed by 201 domestic tourists (\%71.53) and 80 foreign tourists (\%28.47). Most domestic tourists were \%9.06 from Isfahan province, \%8.33 from Tehran and \%7.97 from Mashhad. Most foreign tourists included \%5.07 from Paris and \%2.5 from Switzerland. In terms of age, the highest frequency belonged to \%55.56 of tourists aged from 21 to 35 years old and then to the age range of 36 to 50 years old. About \%67.86 of tourists checked weather conditions to determine the destination of their trips and about \%60.85 of them were aware of the best time of climatic conditions for visiting the historical sites of Isfahan.

\subsubsection{Thermal Comfort Sensation of Tourists}

Since the questionnaire was completed in the warmest month of the year, the thermal comfort sensation of tourists was more inclined to the warm range. The distribution of interviewees' thermal sensation is shown in Figure 8.

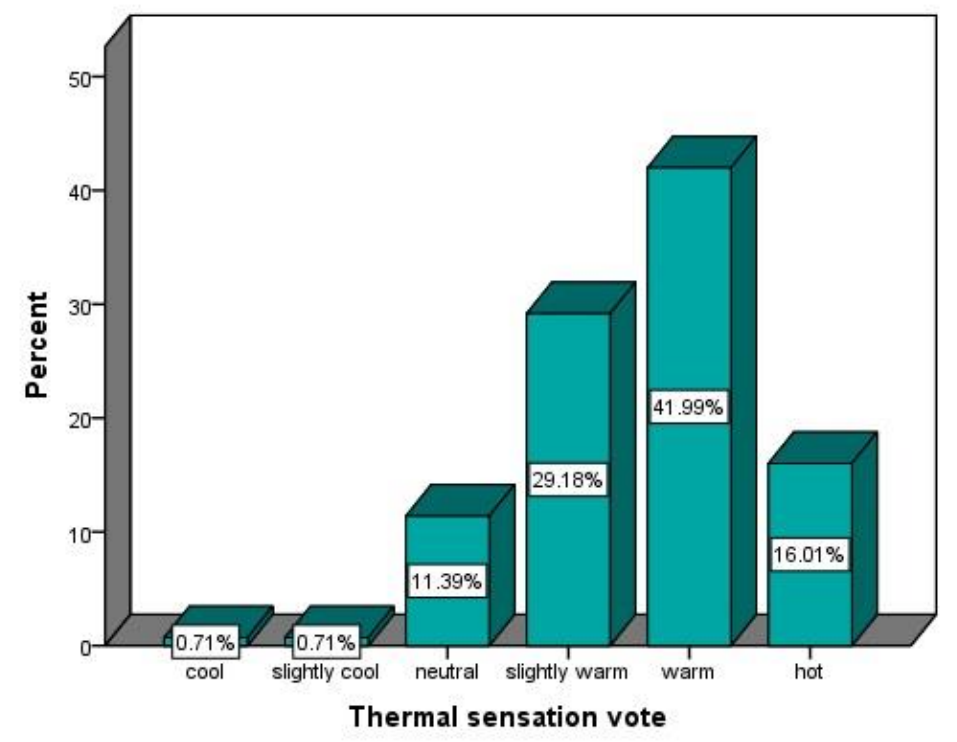

Figure 8. Percentage distributions of thermal sensation votes (TSV) in the study

Similar to previous studies [72-73], with the increased time of presence in the site, tourists had less feeling of warmth. With the increased feeling of warmth, tourists' comfort level decreased, and their dissatisfaction with the thermal conditions and their preference for cooler conditions 
increased. With the increased level of shading, their thermal sensation tended to feel cooler. There was not any relationship between tourists' emotional states (happiness and sadness) and their thermal comfort sensation ( $\mathrm{P}$ value $>.05$ ). The significance of the relationship between thermal comfort sensation of tourists and different factors is presented in Table 6.

Table 6. Gamma correlation for thermal sensation and other parameters.

\begin{tabular}{|c|c|c|c|c|}
\hline Parameters & & Value coefficient & Approx. Sig & Description \\
\hline \multirow{5}{*}{$\begin{array}{l}\text { Thermal } \\
\text { sensation }\end{array}$} & Exposure time & -.267 & .001 & $\checkmark$ \\
\hline & Mental condition of tourists & .031 & .699 & - \\
\hline & Thermal preference & -.360 & .000 & $\checkmark$ \\
\hline & Thermal Satisfaction & -.287 & .000 & $\checkmark$ \\
\hline & Thermal comfort & -.274 & .001 & $\checkmark$ \\
\hline
\end{tabular}

\subsubsection{Thermal Comfort Satisfaction of Tourists}

According to the results of the questionnaire, about $\% 48.21$ of the tourists were satisfied, $\% 21.07$ were slightly satisfied and \%9.29 were very satisfied with the thermal conditions. Despite the high heat stress, tourists' satisfaction might be associated with their expectation from this warm period of the year. The percentage of tourists' satisfaction is shown in Figure 9. 


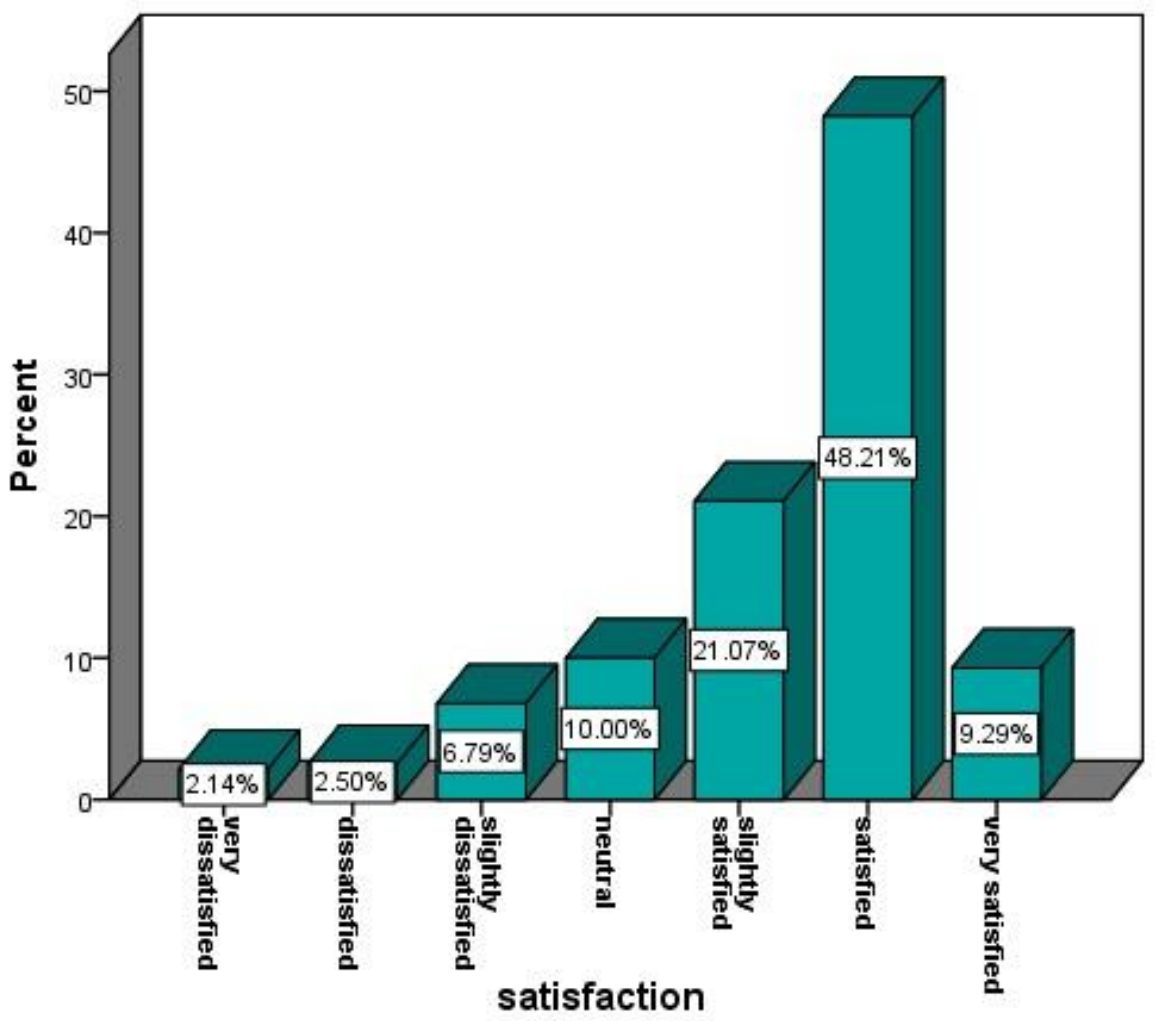

Figure 9. Percentage distributions of satisfaction in outdoor space of historical place.

\subsubsection{Thermal Comfort Zone of Tourists}

The measured air temperature, relative humidity and wind speed while completing the questionnaires, as well as the simulated average temperature were used as input parameters in RayMan to calculate PET. Due to the lack of Mean Radiant Temperature $\left(\mathrm{T}_{\mathrm{mrt}}\right)$ measurement tools, simulation outputs were used in the points where questionnaires were completed. The PET index was calculated at the metabolic rate of 80 Watt for a man of 35 years old with $1.75 \mathrm{~cm}$ tall, and 75 $\mathrm{kg}$ weight in RayMan. The metabolic rate of 80 Watt is a normal rate for one who walks at the speed of 1.2 meters per second.

There was a correlation between the PET value and interviewees' response to thermal sensation. Based on the recommended method in the study [74], the Mean Thermal Sensation Vote (MSTV) was calculated for each one-degree change in the value of PET. Figure 10 shows the regression between these two variables. Equation 1 expresses the relationship between PET and MTSV. The thermal comfort zone is located in 7 points ranging from -0.5 to +0.5 according to thermal 
sensation scale. Therefore, thermal comfort sensation of tourists about the historical site and monuments of Isfahan ranges from 23.06 to $29.73{ }^{\circ} \mathrm{C}$ PET.

$$
\left(M T S V=-3.96+0.15 * P E T \quad\left(R^{2}=0.84\right) \quad\right. \text { Eq. (1) }
$$

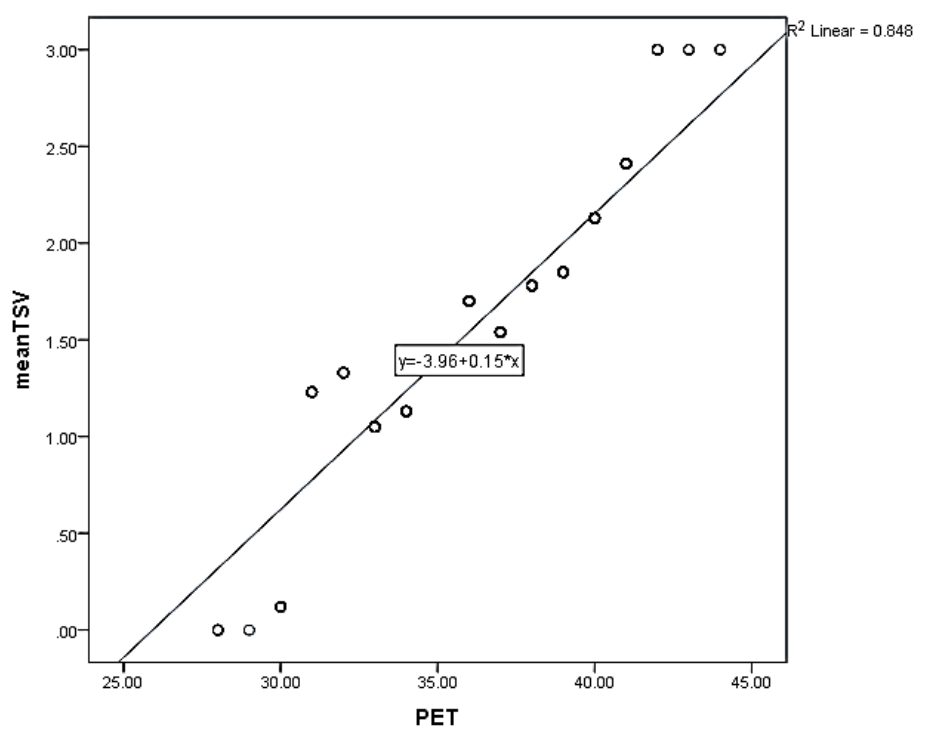

Figure 10. Correlation between the mean thermal sensation votes (MTSVs) and PET in July

Different climates have different comfort ranges [75-76]. Furthermore, different seasons have different thermal comfort range due to different expectations. In other words, cold seasons have a lower comfort range than warm seasons ([77-79]. Figure 11 presents PET's thermal comfort ranges in previous studies on different climates.

In the present study, the comfort range has approximated to the thermal comfort range of arid climates as well as subtropical climates. Since this study was conducted in the warmest month of the year, the thermal comfort range included high level of PET which is higher than the range of $18-23^{\circ} \mathrm{C}$ in central and west Europe. In this study, different tourists, residing in different climates, participated in completing the research questionnaire which affected the determination of thermal comfort zone and resulted in the extensiveness of comfort range over the $18-23{ }^{\circ} \mathrm{C}$ range. 


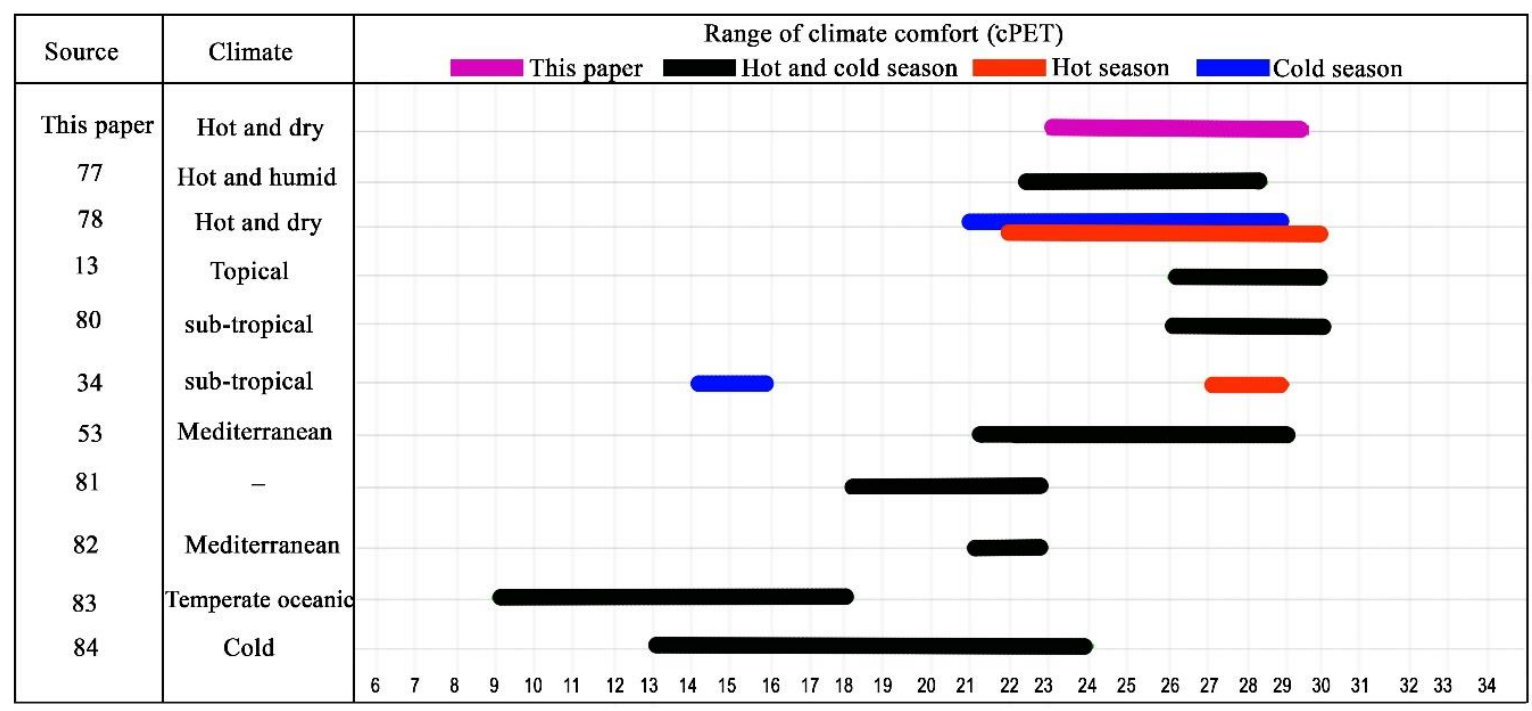

Figure 11. Thermal comfort range of PET in different study.

\subsection{Simulation results}

\subsubsection{Mean Radiant Temperature in Different Urban Textures}

The mean radiant temperature is a crucial factor in determining PET's comfort index [85]. Different points were considered in each historical site to assess their PET index (Figure. 12). $\mathrm{T}_{\mathrm{mrt}}$ maps of each historical texture is shown in Figure 13, and $\mathrm{T}_{\text {mrt }}$ diagrams of the intended points are illustrated in Figure 14. The shades of trees, subsidence and walls of Naqsh-e-Jahan Square reduced $\mathrm{T}_{\mathrm{mrt}}$. The shades of walls had a more important role in the reduction of mean radiant temperature than the shades of tress so that their values were $23{ }^{\circ} \mathrm{C}$ apart at $5 \mathrm{pm}$. Flooring created different $T_{\text {mrt. }}$. In the peak hours of heat, the difference between $T_{m r t}$ of grassland and stone flooring of the square was $7{ }^{\circ} \mathrm{C}$. 


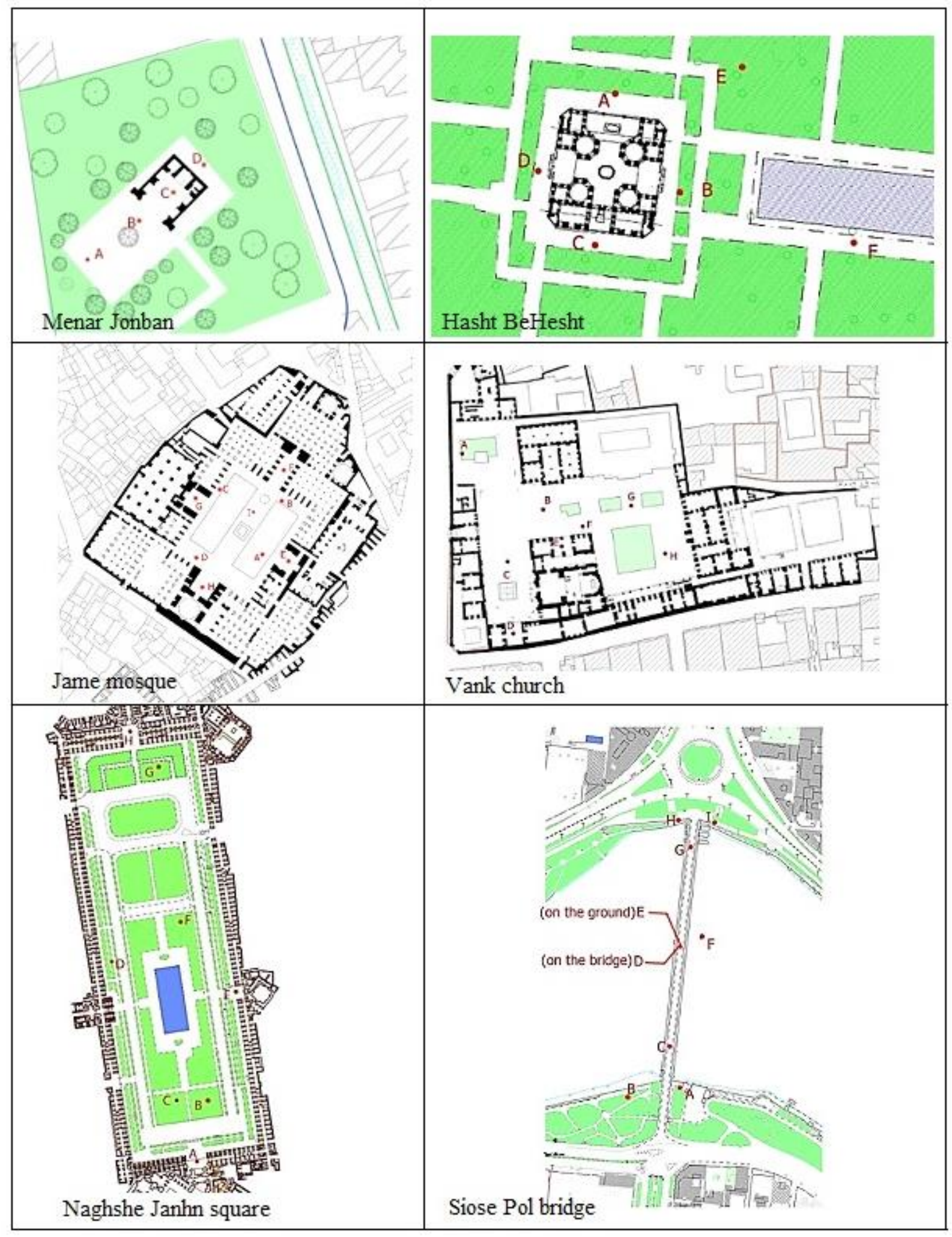

Figure 12. Location of different check points in each historical place. 


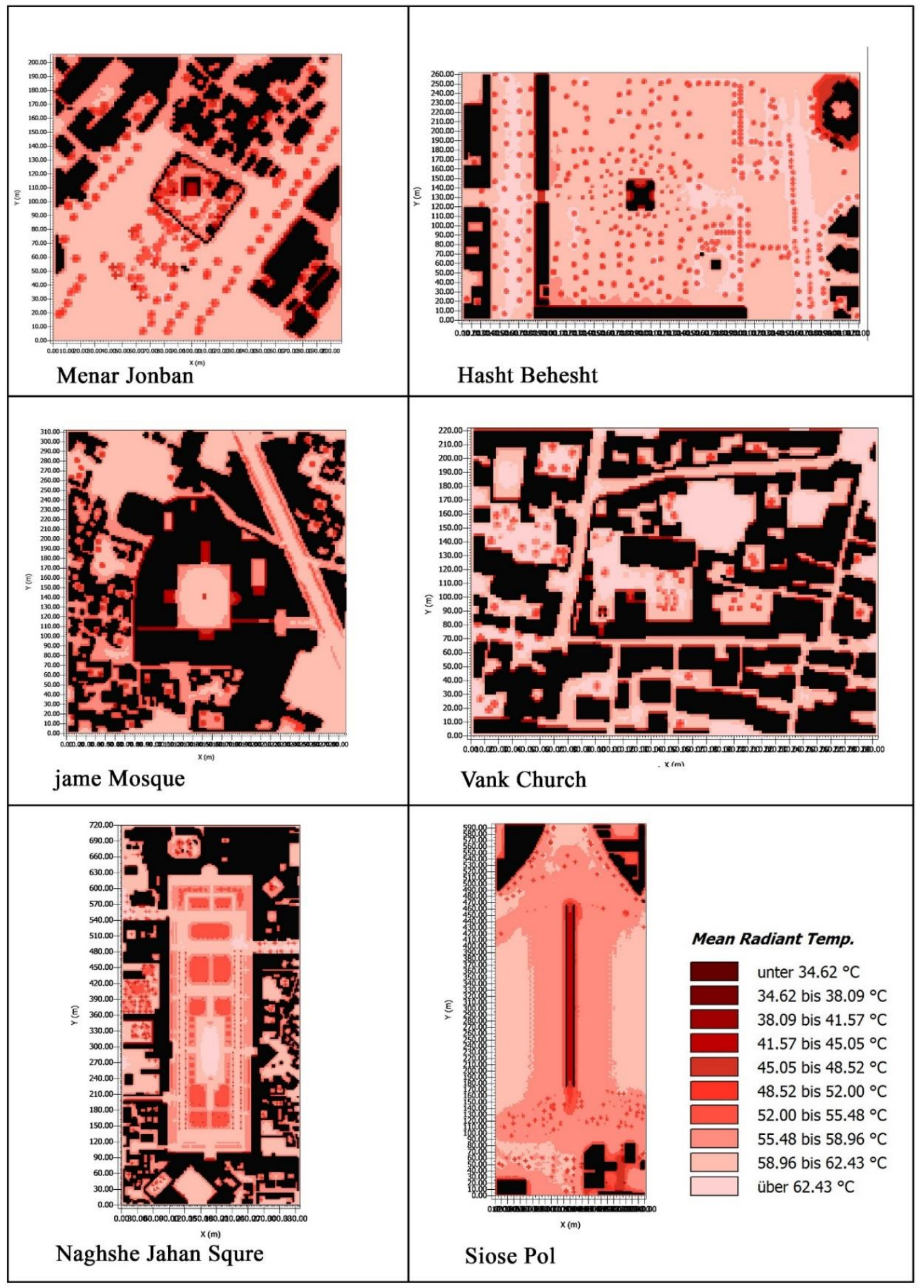

Figure 13. Tmrt map at 12:00 for each survey place in hottest month. 

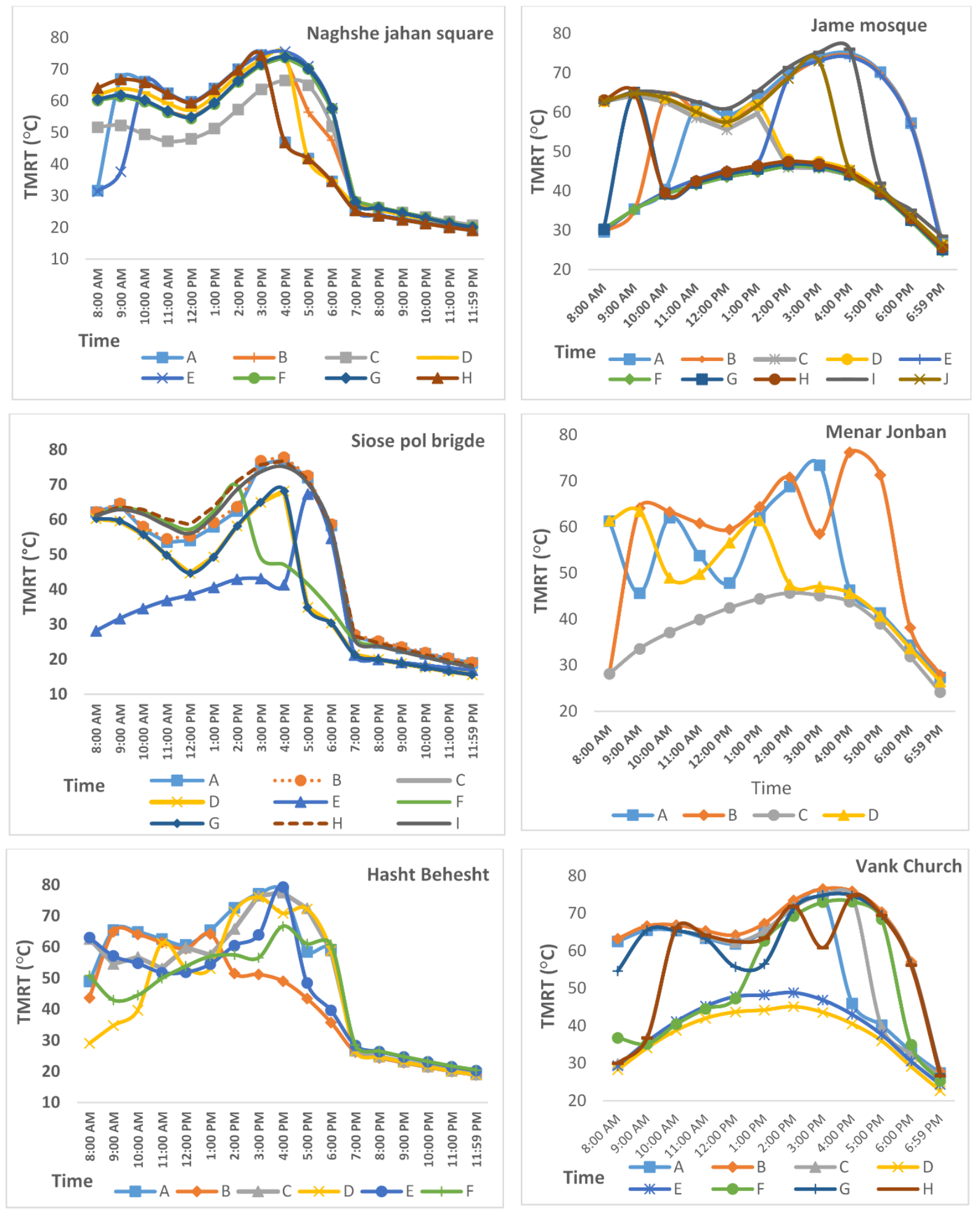

Figure 14. Tmrt in check points of each historical place in hottest month. 
In Masjed-e-Jame, Tmrt of the northern and eastern walls and Tmrt of the southern and western walls was lower. The eastern porch as well as the western and southern porches had lower radiant temperature respectively in the morning and in the afternoon. At $4 \mathrm{pm}$, the difference between Tmrt of eastern and northern porches reached $27{ }^{\circ} \mathrm{C}$. The difference between Tmrt of shaded and unshaded sites of the central yard exceeded $30{ }^{\circ} \mathrm{C}$ at 8 am and $4 \mathrm{pm}$. In general, the lowest Tmrt belonged to the northern porch (Point F) and the highest Tmrt was related to the vicinity of the northern walls (Point B).

The point drawn under the bridge was in the shade at all hours of the day except for 4 and $7 \mathrm{pm}$ and had a lower Tmrt compared with other points. Tmrt decreased in the points C, D and G on the bridge due to the shading of western and eastern walls in comparison to points $\mathrm{A}, \mathrm{B}, \mathrm{I}$, and $\mathrm{H}$. This difference reached about $35^{\circ} \mathrm{C}$ at $5 \mathrm{pm}$.

According to the diagram of mean radiant temperature in different points of Menar-e-Jonban, Tmrt was lower in the porch space than other parts. The point on the central area (B) had the highest Tmrt. This difference reached $30{ }^{\circ} \mathrm{C}$ at $4 \mathrm{pm}$.

In the historical palace of Hasht Behesht, the western zone in the morning and the eastern zone in the evening were in the shade and their Tmrt decreased. Tmrt dropped (about $10{ }^{\circ} \mathrm{C}$ ) under the trees during the daytime.

The value of Tmrt was lower in Vank Cathedral than other sites. This parameter had the highest value in the central yard. The difference between Tmrt of the porch and central yards was $32{ }^{\circ} \mathrm{C}$ at 9 am and $35^{\circ} \mathrm{C}$ at $4 \mathrm{pm}$. The shading of buildings had a significant effect on the reduction of Tmrt. Only pine trees have been used in this historical texture; Due to the small size of their canopy, the pine trees had limited shading and decreased Tmrt in a small area (average $10^{\circ} \mathrm{C}$ reduction in Tmrt value).

\subsubsection{Comparison of Thermal Conditions in Different Urban Textures}

In order to compare the thermal comfort conditions in different historical textures, the mean of air temperature, relative humidity, wind speed, and mean radiant temperature was calculated in the intended points of each historical site and their data were used as inputs to estimate PET's thermal comfort index in RayMan software. 
The thermal comfort conditions in the simulated microclimates of each historical site were different from other sites during the hours of the day. In the daytime, the comfort conditions of different historical sites ranged from $4.9{ }^{\circ} \mathrm{C}$ of PET at 8 am to $8.1{ }^{\circ} \mathrm{C}$ of PET at $3 \mathrm{pm}$; from $6 \mathrm{pm}$ on, the thermal comfort conditions of Naqgh-e-Jahan, Si-o-Se Pol and Hasht Behesht have reached to the favorable thermal comfort range (Figure 15).

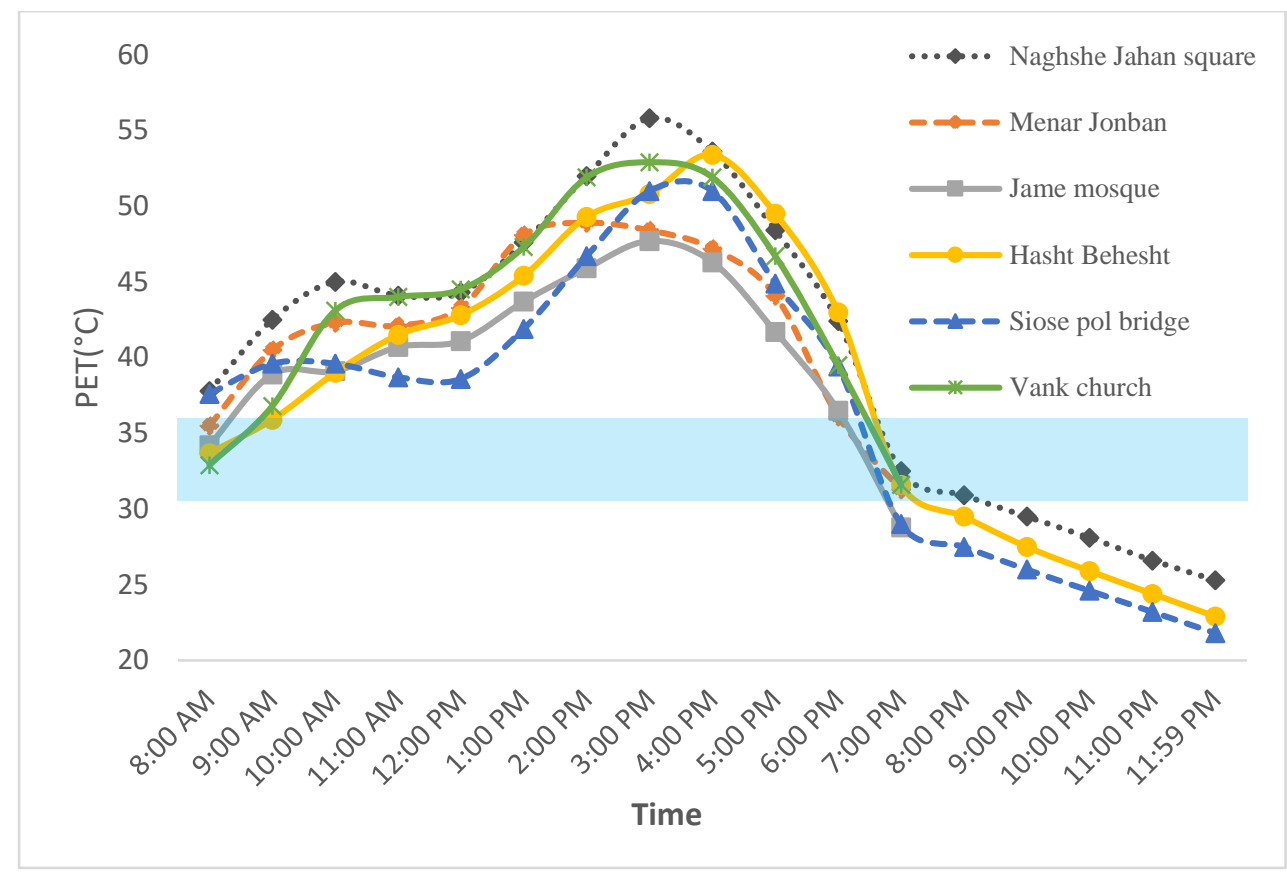

Figure 15. Thermal comfort of historical place in different time in hottest month.

Thermal comfort calendar shows the most suitable time to visit each historical site in a day with the average warmest month of the year (Figure 16). The thermal conditions of the intended historical sites were determined in two-hours intervals from 8 am to $12 \mathrm{pm}$. Each color represents a $3{ }^{\circ} \mathrm{C}$ range of PET's thermal index. The last columns of comparison table present the most favorable and most unfavorable thermal comfort spaces. For instance, the thermal conditions of Si-o-Se Pol and Masjed-e-Jame were similar in the time interval of 10 to 12 am indicating that these historical sites took the first priority for visit in terms of thermal comfort. After these sites, Hasht Behesht, Menar-e-Jonban and Vank Cathedral took the second priority. Naqsh-e-Jahan had the third priority in terms of thermal comfort. Masjed-e-Jame of Isfahan was a better choice to visit in the peak hours of heat than other sites. Semi-open spaces and shading of walls in the central yard of this historical site created more favorable microclimates than other sites. In Naqsh-e-Jahan 
square, lack of favorable shading of tress provided more unfavorable thermal comfort conditions than other historical sites.

\begin{tabular}{|c|c|c|c|c|c|c|c|c|c|c|}
\hline Time & $\begin{array}{l}\text { Vank } \\
\text { church (6) }\end{array}$ & $\begin{array}{l}\text { Jame } \\
\text { mosque (5) }\end{array}$ & $\begin{array}{l}\text { Menar } \\
\text { Jonban (4) }\end{array}$ & $\begin{array}{l}\text { Siose Pol } \\
\text { (3) }\end{array}$ & $\begin{array}{l}\text { Hasht } \\
\text { Behesht (2) }\end{array}$ & $\begin{array}{l}\text { Naghshe Jahan } \\
\text { square (1) }\end{array}$ & Inadequate & Adequate & 23-26 & ${ }^{\circ} \mathrm{CPET}$ \\
\hline 8-10AM & & & & & & & 1 & $6,5,2$ & $20.1-29$ & "CPET \\
\hline $10-12 \mathrm{AM}$ & & & & & & & 1 & 5,3 & $32.1-35$ & ¿CPET \\
\hline 12-14PM & & & & & & & 6,1 & 5,3 & $35.1-38$ & ${ }^{\circ C} \mathrm{PET}$ \\
\hline 14-16PM & & & & & & & $6,2,1$ & 5 & $38.1-41$ & ${ }^{\circ} \mathrm{CPET}$ \\
\hline 16-18PM & & & & & & & $6,2,1$ & 5,4 & $41.1-44$ & ${ }^{\circ} \mathrm{CPET}$ \\
\hline 18-20PM & Time out & Time out & Time out & & & & 1 & 3 & $44.1-47$ & ${ }^{\circ C}$ PET \\
\hline 20-22PM & Time out & Time out & Time out & & & & 3,2 & 3 & $47.1-50$ & ¿CPET \\
\hline 22-24PM & Time out & Time out & Time out & & & & - & $2,3,1$ & $50.1-54$ & ${ }^{\circ} \mathrm{PP}$ \\
\hline
\end{tabular}

Figure 16. Thermal comfort calendar of the historical places in average during hottest month.

\subsection{Comparison of Simulation and Questionnaire Results}

In the simulation models, three historical sites with higher thermal comfort conditions (Masjed-eJame, Si-o-Se Pol, Menar-e-Jonban) received higher satisfaction level in the questionnaires. On the contrary, three historical sites with lower thermal comfort conditions (Hasht Behesht, Vank Cathedral, Naqsh-e-Jahan) received lower satisfaction level. Naqsh-e-Jahan square had the highest percentage of dissatisfaction (\%25). According to the results of simulation, Naqsh-e-Jahan square had the worst thermal comfort conditions during the day in comparison to other historical sites. After Naqsh-e-Jahan square, the Hasht Behesht palace had higher percentage of dissatisfaction than other sites; this might be due to the people's expectation from Hasht Behesht Palace. That is, people expected more favorable thermal comfort conditions across the palace. Therefore, their satisfaction level with thermal comfort in this site decreased. Table 7 shows the percentage of tourists' satisfaction with each historical site.

Table7. Thermal satisfaction of tourist in historical palce in hottest month.

\begin{tabular}{lccc}
\hline Historical place & Satisfaction (\%) & Neutral(\%) & Dissatisfaction (\%) \\
\hline Naghshe jahan square & 75 & 8.33 & $\mathbf{2 5}$ \\
\hline Jame mosque & 79.17 & 18.75 & $\mathbf{2 . 0 8}$ \\
\hline Vank church & 75 & 14.58 & $\mathbf{1 0 . 4 2}$ \\
\hline Menar Jonban & 91.11 & 6.67 & $\mathbf{2 . 2 2}$ \\
\hline Hasht Behesht & 71.74 & 6.52 & $\mathbf{2 1 . 7 4}$ \\
\hline Siose pol bridge & 80.01 & 4.44 & $\mathbf{1 5 . 5 5}$ \\
\hline
\end{tabular}




\section{Conclusion}

Due to its economic value, tourism industry is one the most important industries of the world. Studies on tourism have been conducted in a large scale (city, country or continent) using data provided by different meteorological stations. These studies determine the thermal comfort conditions by using meteorological data regardless of microclimates created in urban texture. The present study intended to evaluate thermal comfort conditions in the microclimates of the valuable urban historical textures of Isfahan in a day with severe heat stress.Historical textures in Isfahan attracts many tourists every year. In the present study, the research scale was limited to the most important historical textures to evaluate the thermal comfort conditions within their microclimates.

The thermal comfort sensation of tourists at the historical textures of Isfahan ranges from 23.06 to $29.73{ }^{\circ} \mathrm{C}$ of PET. Despite the high heat stress, about $\% 78.57$ of tourist were satisfied with the thermal conditions while $\% 11.43$ were dissatisfied. This indicates the psychological compatibility of tourists with the conditions despite the high heat stress.

The thermal conditions of the historical sites of Naqsh-e-Jahan, Hasht Behesht and Si-o-Se Pol have reached to the favorable comfort range at $8 \mathrm{pm}$ to $12 \mathrm{am}$ at midnight that are the best time to visit these historical sites. The best time to visit the historical sites of Menar-e-Jonban, Masjed-eJame and Vank Cathedral is the early morning hours. In the peak hours of heat ( 2 to $4 \mathrm{pm}$ ), the first priority goes to Masjed-e-Jame and then to Menar-e-Jonban and Si-o-Se Pol in terms of thermal comfort. The shading of spaces has a crucial role in the reduction of heat stress. Semiopen spaces and shading of walls of Masjed-e-Jame of Isfahan provides more suitable thermal conditions than other sites. Lack of appropriate shading in Naqsh-e-Jahan, creates unfavorable thermal comfort condition during the daytime. Floorings creates different $\mathrm{T}_{\mathrm{mrt}}$. In the peak hours

of heat, the difference between the grassland and stone flooring of the square reaches to $7{ }^{\circ} \mathrm{C}$ of $\mathrm{T}_{\mathrm{mrt}}$. According to the results of the questionnaire, tourists are more satisfied with the thermal comfort conditions of the historical textures and site with more favorable thermal comfort conditions.

\section{References}


[1] Matzarakis, A. (2006). Weather-and climate-related information for tourism. Tourism and Hospitality Planning \& Development, 3(2), 99-115.

[2] de Freitas, C. R., Scott, D., \& McBoyle, G. (2008). A second generation climate index for tourism (CIT): specification and verification. International Journal of Biometeorology, 52(5), 399-407.

[3] Bigano, A., Hamilton, J. M., \& Tol, R. S. (2006). The impact of climate on holiday destination choice. Climatic Change, 76(3-4), 389-406.

[4] Eugenio-Martin, J. L., \& Campos-Soria, J. A. (2010). Climate in the region of origin and destination choice in outbound tourism demand. Tourism Management, 31(6), 744-753.

[5] Ridderstaat, J., Oduber, M., Croes, R., Nijkamp, P., \& Martens, P. (2014). Impacts of seasonal patterns of climate on recurrent fluctuations in tourism demand: Evidence from Aruba. Tourism Management, 41, 245-256.

[6] Lu, S., Xia, H., Wei, S., Fang, K., \& Qi, Y. (2016). Analysis of the differences in thermal comfort between locals and tourists and genders in semi-open spaces under natural ventilation on a tropical island. Energy and Buildings, 129, 264-273.

[7] Matzarakis, A., \& Mayer, H. (1997). Heat stress in Greece. International Journal of Biometeorology, 41(1), 34-39.

[8] Lin, T. P., \& Matzarakis, A. (2011). Tourism climate information based on human thermal perception in Taiwan and Eastern China. Tourism Management, 32(3), 492-500.

[9] Lecha, L., \& Shackleford, P. (1997). Climate services for tourism and recreation. Bulletin of the World Meteorological Organization, 46(1), 46-46.

[10] Farajzadeh, H., \& Matzarakis, A. (2012). Evaluation of thermal comfort conditions in Ourmieh Lake, Iran. Theoretical and Applied Climatology, 107(3-4), 451-459.

[11] Spagnolo, J. C., \& De Dear, R. J. (2003). A human thermal climatology of subtropical Sydney. International Journal of Climatology, 23(11), 1383-1395. 
[12] Vitt, R., Gulyás, Á., \& Matzarakis, A. (2015). Temporal differences of urban-rural human biometeorological factors for planning and tourism in Szeged, Hungary. Advances in Meteorology, 2015.

[13] de Freitas, C. R. (2003). Tourism climatology: evaluating environmental information for decision making and business planning in the recreation and tourism sector. international Journal of Biometeorology, 48(1), 45-54.

[14] Lin, T. P., \& Matzarakis, A. (2008). Tourism climate and thermal comfort in Sun Moon Lake, Taiwan. International Journal of Biometeorology, 52(4), 281-290.

[15] Mieczkowski, Z. (1985). The tourism climatic index: a method of evaluating world climates for tourism. The Canadian Geographer/Le Géographe canadien, 29(3), 220-233.

[16] Yan, Y. Y. (2005). Human thermal climates in China. Physical Geography, 26(3), 163-176.

[17] Çalışkan, O., Çiçek, I., \& Matzarakis, A. (2012). The climate and bioclimate of Bursa (Turkey) from the perspective of tourism. Theoretical and Applied Climatology, 107(3-4), 417-425.

[18] Shiue, I., \& Matzarakis, A. (2011). Estimation of the tourism climate in the Hunter Region, Australia, in the early twenty-first century. International journal of biometeorology, 55(4), 565574.

[19] Matzarakis, A., Rammelberg, J., \& Junk, J. (2013). Assessment of thermal bioclimate and tourism climate potential for central Europe-the example of Luxembourg. Theoretical and applied climatology, 114(1-2), 193-202.

[20] Wang, S., He, Y., \& Song, X. (2010). Impacts of climate warming on alpine glacier tourism and adaptive measures: A case study of Baishui Glacier No. 1 in Yulong Snow Mountain, Southwestern China. Journal of Earth Science, 21(2), 166-178.

[21] Rosselló-Nadal, J. (2014). How to evaluate the effects of climate change on tourism. Tourism Management, 42, 334-340.

[22] Berrittella, M., Bigano, A., Roson, R., \& Tol, R. S. (2006). A general equilibrium analysis of climate change impacts on tourism. Tourism management, 27(5), 913-924. 
[23] Hamilton, J. M., \& Tol, R. S. (2007). The impact of climate change on tourism in Germany, the UK and Ireland: a simulation study. Regional Environmental Change, 7(3), 161-172.

[24] Scott, D., Jones, B., \& Konopek, J. (2007). Implications of climate and environmental change for nature-based tourism in the Canadian Rocky Mountains: A case study of Waterton Lakes National Park. Tourism management, 28(2), 570-579.

[25]Amelung, B., \& Moreno, A. (2012). Costing the impact of climate change on tourism in Europe: results of the PESETA project. Climatic Change, 112(1), 83-100.

[26] Oke, T. R. (1988). Street design and urban canopy layer climate. Energy and buildings, 11(1), 103-113.

[27] Liu, W., Zhang, Y., \& Deng, Q. (2016). The effects of urban microclimate on outdoor thermal sensation and neutral temperature in hot-summer and cold-winter climate. Energy and Buildings, 128, 190-197.

[28] Chen, H., Ooka, R., Harayama, K., Kato, S., \& Li, X. (2004). Study on outdoor thermal environment of apartment block in Shenzhen, China with coupled simulation of convection, radiation and conduction. Energy and Buildings, 36(12), 1247-1258.

[29] Zacharias, J., Stathopoulos, T., \& Wu, H. (2001). Microclimate and downtown open space activity. Environment and Behavior, 33(2), 296-315.

[30] Acero, J. A., \& Herranz-Pascual, K. (2015). A comparison of thermal comfort conditions in four urban spaces by means of measurements and modelling techniques. Building and Environment, 93, 245-257.

[31] Nastos, P. T., \& Matzarakis, A. (2012). The effect of air temperature and human thermal indices on mortality in Athens, Greece. Theoretical and Applied Climatology, 108(3-4), 591-599.

[32] Nikolopoulou, M., \& Lykoudis, S. (2007). Use of outdoor spaces and microclimate in a Mediterranean urban area. Building and environment, 42(10), 3691-3707. 
[33] Strømann-Andersen, J., \& Sattrup, P. A. (2011). The urban canyon and building energy use: Urban density versus daylight and passive solar gains. Energy and Buildings, 43(8).

34- Ng, E., \& Cheng, V. (2012). Urban human thermal comfort in hot and humid Hong Kong. Energy and Buildings, 55, 51-65.

[35] Ahmed, K. S. (2003). Comfort in urban spaces: defining the boundaries of outdoor thermal comfort for the tropical urban environments. Energy and Buildings, 35(1), 103-110.

[36] Jamei, E., Rajagopalan, P., Seyedmahmoudian, M., \& Jamei, Y. (2016). Review on the impact of urban geometry and pedestrian level greening on outdoor thermal comfort. Renewable and Sustainable Energy Reviews, 54, 1002-1017.

[37] Abreu-Harbich, L. V., Labaki, L. C., \& Matzarakis, A. (2014). Thermal bioclimate in idealized urban street canyons in Campinas, Brazil. Theoretical and applied climatology, 115(1-2), 333-340. [38] Yan, H., Fan, S., Guo, C., Wu, F., Zhang, N., \& Dong, L. (2014). Assessing the effects of landscape design parameters on intra-urban air temperature variability: the case of Beijing, China. Building and environment, 76, 44-53.

[39] Charalampopoulos, I., Tsiros, I., Chronopoulou-Sereli, A., \& Matzarakis, A. (2013). Analysis of thermal bioclimate in various urban configurations in Athens, Greece. Urban Ecosystems, 16(2), 217-233.

[40] Giannopoulou, K., Livada, I., Santamouris, M., Saliari, M., Assimakopoulos, M., \& Caouris, Y. G. (2011). On the characteristics of the summer urban heat island in Athens, Greece. Sustainable Cities and Society, 1(1), 16-28.

[41] Emmanuel, R., \& Johansson, E. (2006). Influence of urban morphology and sea breeze on hot humid microclimate: the case of Colombo, Sri Lanka. Climate research, 30(3), 189-200.

[42] Morakinyo, T. E., Dahanayake, K. K. C., Adegun, O. B., \& Balogun, A. A. (2016). Modelling the effect of tree-shading on summer indoor and outdoor thermal condition of two similar buildings in a Nigerian university. Energy and Buildings, 130, 721-732. 
[43] Salata, F., Golasi, I., de Lieto Vollaro, A., \& de Lieto Vollaro, R. (2015). How high albedo and traditional buildings' materials and vegetation affect the quality of urban microclimate. A case study. Energy and Buildings, 99, 32-49.

[44] Kottek, M., Grieser, J., Beck, C., Rudolf, B., \& Rubel, F. (2006). World map of the KöppenGeiger climate classification updated. Meteorologische Zeitschrift, 15(3), 259-263.

[45] Meteorological Organization Country: http://www.irimo.ir

[46] ISO. International Standard 7726, thermal environment-instruments and method for measuring physical quantities. Geneva: International Standard Organization; 1998.

[47] Oliveira, S., \& Andrade, H. (2007). An initial assessment of the bioclimatic comfort in an outdoor public space in Lisbon. International Journal of Biometeorology, 52(1), 69-84.

[48] Lai, D., Guo, D., Hou, Y., Lin, C., \& Chen, Q. (2014). Studies of outdoor thermal comfort in northern China. Building and Environment, 77, 110-118.

[49] Sharmin, T., Steemers, K., \& Matzarakis, A. (2015). Analysis of microclimatic diversity and outdoor thermal comfort perceptions in the tropical megacity Dhaka, Bangladesh. Building and Environment, 94, 734-750.

[50] ASHRAE. (2005). Handbook of fundamentals. Atlanta, GA: American Society of Heating, Refrigerating and Air-Conditioning Engineers.

[51] Johansson, E., Thorsson, S., Emmanuel, R., \& Krüger, E. (2014). Instruments and methods in outdoor thermal comfort studies-the need for standardization. Urban Climate, 10, 346-366.

[52] Villadiego, K., \& Velay-Dabat, M. A. (2014). Outdoor thermal comfort in a hot and humid climate of Colombia: a field study in Barranquilla. Building and Environment, 75, 142-152.

[53] Salata, F., Golasi, I., de Lieto Vollaro, R., \& de Lieto Vollaro, A. (2016). Outdoor thermal comfort in the Mediterranean area. A transversal study in Rome, Italy. Building and Environment, $96,46-61$. 
[54] Chen, L., Wen, Y., Zhang, L., \& Xiang, W. N. (2015). Studies of thermal comfort and space use in an urban park square in cool and cold seasons in Shanghai. Building and Environment, 94, 644653.

[55] Taleb, D., \& Abu-Hijleh, B. (2013). Urban heat islands: Potential effect of organic and structured urban configurations on temperature variations in Dubai, UAE. Renewable energy, 50, 747-762.

[56] Johansson, E. (2006). Influence of urban geometry on outdoor thermal comfort in a hot dry climate: a study in Fez, Morocco. Building and environment, 41(10), 1326-1338.

[57] Wong, N. H., Jusuf, S. K., La Win, A. A., Thu, H. K., Negara, T. S., \& Xuchao, W. (2007). Environmental study of the impact of greenery in an institutional campus in the tropics. Building and environment, 42(8), 2949-2970.

[58] Srivanit, M., \& Hokao, K. (2013). Evaluating the cooling effects of greening for improving the outdoor thermal environment at an institutional campus in the summer. Building and Environment, 66, 158-172.

[59] Bruse, M., Bürger, M., Bohnstedt, A., Ihde, A., Jesionek, K., \& Lahme, E. (2002). Measurements and model simulations in WP MICRORuhr-University Bochum. Institute of Geography, Research Group Climatology.

[60] M. Bruse, ENVI-met 4 (2014). http://www.envi-met.info.

[61] Fanger PO (1972) Thermal comfort. McGraw Hill, New York.

[62] Parsons KC (1993) Human thermal environments. Taylor \& Francis, London

[63] Blazejczyk, K., Epstein, Y., Jendritzky, G., Staiger, H., \& Tinz, B. (2012). Comparison of UTCl to selected thermal indices. International journal of biometeorology, 56(3), 515-535.

[64] Jendritzky, G., Maarouf, A., Fiala, D., \& Staiger, H. (2002, October). An update on the development of a Universal Thermal Climate Index. In 15th Conf. Biomet. Aerobiol. and 16th ICB02 (Vol. 27, pp. 129-133). 
[65] Fiala, D., Lomas, K. J., \& Stohrer, M. (1999). A computer model of human thermoregulation for a wide range of environmental conditions: the passive system. Journal of Applied Physiology, 87(5), 1957-1972.

[66] Höppe, P. (1999). The physiological equivalent temperature-a universal index for the biometeorological assessment of the thermal environment. International journal of Biometeorology, 43(2), 71-75.

[67] Kurazumi, Y., Tsuchikawa, T., Matsubara, N., Kondo, E., \& Horikoshi, T. (2011). Evaluation of enhanced conduction-corrected modified effective temperature ETFe as the outdoor thermal environment evaluation index. Energy and Buildings, 43(10), 2926-2938.

[68] Matzarakis, A., Rutz, F., \& Mayer, H. (2007). Modelling radiation fluxes in simple and complex environments-application of the RayMan model. International journal of biometeorology, 51(4), 323-334.

[69] Lin, T. P., Matzarakis, A., \& Hwang, R. L. (2010). Shading effect on long-term outdoor thermal comfort. Building and Environment, 45(1), 213-221.

[70] VDI. Methods for the human biometeorological evaluation of climate and airquality for the urban and regional planning. Part I: Climate. VDI guildline 3787. Part 2. Berlin: Beuth; 1998.

[71] Ali-Toudert, F., \& Mayer, H. (2006). Numerical study on the effects of aspect ratio and orientation of an urban street canyon on outdoor thermal comfort in hot and dry climate. Building and environment, 41(2), 94-108.

[72] Makaremi, N., Salleh, E., Jaafar, M. Z., \& GhaffarianHoseini, A. (2012). Thermal comfort conditions of shaded outdoor spaces in hot and humid climate of Malaysia. Building and environment, 48, 7-14.

[73] Pantavou, K., Theoharatos, G., Santamouris, M., \& Asimakopoulos, D. (2013). Outdoor thermal sensation of pedestrians in a Mediterranean climate and a comparison with UTCI. Building and Environment, 66, 82-95. 
[74] De Dear, R. J., \& Brager, G. S. (2002). Thermal comfort in naturally ventilated buildings: revisions to ASHRAE Standard 55. Energy and buildings, 34(6), 549-561.

[75] Nikolopoulou, M., Baker, N., \& Steemers, K. (1999). Thermal comfort in urban spaces: different forms of adaptation. Proc. REBUILD 1999: Shaping Our Cities for the 21st Century.

[76] Ruiz, M. A., \& Correa, E. N. (2015). Suitability of different comfort indices for the prediction of thermal conditions in tree-covered outdoor spaces in arid cities. Theoretical and Applied Climatology, 122(1-2), 69-83.

[77] Lin, T. P. (2009). Thermal perception, adaptation and attendance in a public square in hot and humid regions. Building and environment, 44(10), 2017-2026.

[78] Mahmoud, A. H. A. (2011). Analysis of the microclimatic and human comfort conditions in an urban park in hot and arid regions. Building and environment, 46(12), 2641-2656.

[79] Nikolopoulou, M., Baker, N., \& Steemers, K. (2001). Thermal comfort in outdoor urban spaces: understanding the human parameter. Solar energy, 70(3), 227-235.

[80] Lin, T. P., Tsai, K. T., Liao, C. C., \& Huang, Y. C. (2013). Effects of thermal comfort and adaptation on park attendance regarding different shading levels and activity types. Building and environment, 59, 599-611.

[81] Matzarakis, A., Mayer, H., \& Iziomon, M. G. (1999). Applications of a universal thermal index: physiological equivalent temperature. International Journal of Biometeorology, 43(2), 76-84.

[82] Andrade, H., Alcoforado, M. J., \& Oliveira, S. (2011). Perception of temperature and wind by users of public outdoor spaces: relationships with weather parameters and personal characteristics. International journal of biometeorology, 55(5), 665-680.

[83] Krüger, E., Drach, P., Emmanuel, R., \& Corbella, O. (2013). Urban heat island and differences in outdoor comfort levels in Glasgow, UK. Theoretical and applied climatology, 112(1-2), 127-141.

[84] Lai, D., Zhou, C., Huang, J., Jiang, Y., Long, Z., \& Chen, Q. (2014). Outdoor space quality: A field study in an urban residential community in central China. Energy and Buildings, 68, 713-720. 
[85] Lee, H., Holst, J., \& Mayer, H. (2013). Modification of human-bio meteorologically significant radiant flux densities by shading as local method to mitigate heat stress in summer within urban street canyons. Advances in Meteorology, 2013. 